\title{
ARTICLES
}

\section{THE WELLSPRINGS OF LEGAL RESPONSES TO INEQUALITY: A PERSPECTIVE ON PERSPECTIVES}

\author{
HOWARD LESNICK*
}

\begin{abstract}
Different people see different worlds .... The difference is as much a matter of how we see as of what is seen. . . . Darwin saw similarities where Linnaeus saw differences ....1
\end{abstract}

[W]e see the lives of others through lenses of our own grinding . . . 2

In this Article, I attempt to articulate fundamental differences in the ways that people perceive human interaction and the purposes of legal regulation and legal representation. To provide a context, I begin by settimg forth a fairly simple legal problem: a garden-variety case of an "unconscionability" defense to an attempt to enforce a sales contract. My aim, however, is not to analyze and appraise the merits of contending answers to the legal and factual questions presented by the problem. Rather, I use the particular setting of the problem to give voice to three overall perspectives (perhaps "world-views" is a preferable term ${ }^{3}$ ) that I

* Jefferson B. Fordham Professor of Law, University of Pennsylvania.

I am grateful to Jack Balkin, Stephen Burbank, Robert Burt, Gerald Frug, Peter Gabel, Jack Getman, Emily Fowler Hartigan, Jack Himmelsten,, Heidi Hurd, Seth Kreimer, Alice Lesnick, Martha Minow, Stephen Morse, Edward Rock, Robin West, Lucie White, and Jean Zorn for reading and giving me their thoughtful responses to a draft of this Article, and to all of my faculty colleagues at the University of Pennsylvania Law School for their attendance and participation at a nost rewarding session of our Legal Studies Seminar. I am especially mdebted to Alice Lesnick for continuing to bring her depth and clarity of insight to bear on nyy ongoing efforts to think and understand, renewing her life-long gift of the opportunity to learn from one's child. I appreciate the summer financial support of the Ida Russell Cades Memorial Fund of the University of Pennsylvania Law School.

The subtitle of the Article is a tangible, but minor, instance of the nany ways that I have benefitted from Martha Minow's extraordinary article, The Supreme Court 1986 Term-Foreword: Justice Engendered, 101 HARV. L. REV. 10, 57 (1987).

1. A. SMith, COGNitive Styles In LAw Schools 3 (1979).

2. Geertz, Anti Anti-Relativism, 86 AM. ANTHROPOlogist 263, 275 (1984).

3. Elsewhere I have written of a world-view, or consciousness, as "a set of ordering perceptions, priorities, and premises" that shapes one's answers to specific questions. Fro1n within a particular world-view, "answers tend to be perceived as given; their content is initially inuplicit, and if made exphicit tends to be regarded as self-evident and uncontroversially true." Lesnick, The Consciousness of Work and the Values of American Labor Law, 32 BUfFalo L. REv. 833, 842 (1984). 
will call "conservative," "liberal," and "radical," which underlie and channel one's response to the legal and factual questions presented. ${ }^{4} \mathrm{My}$ effort is to give expression to the central perceptions of the several perspectives as I believe they are actually held by legal and political practitioners, rather than as their supporting arguments may be marshalled by scholars or philosophers. ${ }^{5}$ In a final section, I explore the ways in which

A more elegant definition is supplied by the philosopher, W.T. Jones: "By world view I mean a configuration of cognitive and evaluative sets, analogous to the perceptual sets that cause different aspects of the experiential field to 'stand out' and become noticeable ...." Jones, Philosophical Disagreements and World Views, 43 Proceedings \& AdDresses AM. PHiL. Ass'N 24 (1970).

Riclaard Delgado uses a similar term, "mindset," to describe "the bundle of presuppositions, received wisdoms, and slared understandings against a background of which legal and political discourse takes place." Delgado, Storytelling for Oppositionists and Others: A Plea for Narrative, 87 Mich. L. REV. 2411, 2413 (1989). He continues: "Thesc matters are rarely focused on. They are like eyeglasses we have worn a long time. They are nearly mvisible; we use them to scan and interpret the world and only rarely examine them for themselves." Id.

John Griffiths used the term "ideology" to describe the same phenomenon: "that set of beliefs, assumptions, categories of understanding, and the like, which affect and determine the structure of perception ...." Griffiths, Ideology in Criminal Procedure, or A Third "Model" of the Criminal Process, 79 YAlE L.J. 359, 359 n.1 (1970). These behiefs, he asserts, are "enmeshed in the factual and hinguistic premises of argument." Id.

The process that these writers (and see the references in Lesmick, supra, at $842 \mathrm{n} .42$ ) have described goes on with respect to perceptions of "factual" as well as theoretical, political, or ethical matters. In Miclrael Moore's words: "We correct perception constantly, in light of our antecedently held background beliefs about how the world is. Much of the correction is not conscious .... [N]o factual beliefs are jnst inferenceless readoffs of reality." Moore, Moral Reality, 1982 WIS. L. REV. $1061,1110$.

4. For recent examples of a similar approach, see Beermann, A Critical Approach to Section 1983 with Special Attention to Sources of Law, 42 STAN. L. REv. 51, $89-94$ (1989); Frug, Argument as Character, 40 STAN. L. REv. 869 (1988); Schultz, Telling Stories About Women and Work: Judicial Interpretations of Sex Segregation in the Workplace in Title VII Cases Raising the Lack of Interest Argument, 103 HARv. L. REv. 1749, 1800-15 (1990); West, Progressive and Conservatlve Constitutionalism, 88 Mich. L. Rev. 641 (1990).

5. My practice in this regard is consistent with a method espoused (and at times carried out) in much recent theoretical literature-in critical legal theory, feminist theory, critical race theory, law and storytelling, and other manifestations of what Mari Matsuda has felicitously termed "outsider's jurisprudence." Matsuda, Public Response to Racist Speech: Considering the Victim's Story, 87 MICH. L. REv. 2320, 2323 (1989). These approacles have enhanced the academic acceptability (and the density) of this inethod. Consistent with the priority stated in the text, however, I will not embellish this Article with a taxonomy of the literature. The basis of my preference is suggested by the story briefly (but effectively) told in Worden, Overshooting the Target: A Feminist Deconstruction of Legal Education, 34 AM. U.L. REv. 1141, 1151-52 (1985) (describing the importance, and the difficulty, of "writing in a style that conforms to the way one thinks about, and relates to the surrounding world").

I lave not set out to describe the perspectives of specific individuals, most of whom hold views that are not so undiluted a manifestation of a single perspective. Moreover, I do not present a thoroughly comprelensive portrait of each perspective. The portraits drawn, although hopefully full enough to be recognized as a "world-view" and not merely a response to a single lawsuit, evidence the "consuiner law," "class" focns of the specific problem that I have closen. That choice is not a statement about the salience of class, relative to other bases of difference, in accounting for or responding to inequality. 
such an approach to legal questions can contribute to a better understanding of the evolution of the law; consider whether and to what extent this approach is coinpatible with the belief that one perspective is preferable to the others; and describe a process by which the approach can aid one to becoine more securely true to one's own perspective, while becoming inore open to recognition of its limitations as well.

I recognize that both the fact of the trichotomization, and the labels that I have attached, will dispose soine to react more skeptically to what I have to say than might otherwise liave been the case. I liave sought, im describing each perspective, to give coinplexities, nuances, and ambivalences their due. I beheve, however, that, this done, fundamental differences in perspective remam, and that it is useful to attempt to articulate them. As for the choice of labels, suffice it to say that, although overworked and soinetimes misleading, these familiar terms most accurately describe the three perspectives as I understand them. ${ }^{6}$ In presenting these perspectives, I atteinpt as rigorously as I can to articulate, rather than to evaluate, eacli of thein. I do not inean any of the appellations as an epithet.

\section{EDUCATIONAL SOFTWARE MATERIALS, INC V. WHITE}

Because much of what follows is about the critical role of one's perspective in shaping responses to legal issues, $I$ behieve that it will facilitate the project to present "the facts" of the problein as they might be known to counsel for the disputants, rather than in the traditional law school manner of a "hypothetical" seen from the single, presumably objective perspective of a disinterested observer. ${ }^{7}$

\section{A. Memorandum to File, from Counsel for ESM}

This law firm represents Educational Software Materials, Inc. (ESM). The company was formed in 1987 by Dorothy Smith, a computer programmer; Joseph Small, an eleinentary school teacher; and Pat Stone, an accountant. ESM develops and markets educational software. Dorothy contributes her programming skills, and Joe his knowledge of

6. Jack Beermann has essayed a very similar approach, using the same three labels, in cousidering judicial treatment of 42 U.S.C. $\$ 1983$. See Beermann, supra note 4.

7. The problem is a shight modification of the setting of a smiulation prepared by several members of the faculty of the City Umiversity of New York Law School at Queens College (of which I was at the time a member) during the academic year 1986-1987. Drafted primarily by Professor Jean Zorn, it is in turn a inodification of a smulation described in Schrag, Terry White: A Two-Front Negotiation Exercise, 88 W. VA. L. REv. 729 (1986).

Randy White and Pat Stone, the clients in the problem, were deliberately given androgynous names by the originators of the simulation. I have, for idiosyncratic reasons, always thought of the former as a man and the latter as a woman, and will so refer to thein here. 
educational needs, to the creation of computer teaching aids. Pat handles the day-to-day busmess side; she is the person with whom we deal.

Beginning with a modest imvestment, ESM has begun to show a profit on its first products-four educational games (in reading, spelling, math, and history) and a recreational game called "Stellar Avenger"although it is still a rather shaky undertaking. ESM sells all of its software by door-to-door sales. It works with a large number of salespersons, all of whom are imdependent contractors working on commission.

Recently, an imcreasing number of buyers have defaulted on their time payments for the products. One of the contracts referred to us for suit pertains to a Randy White. The file indicates nothing unusual about the sale. White bought the coinpany's full package-a personal computer, a set of four software educational games, and "Stellar Avenger"at a total cost of $\$ 2,050.00, \$ 250.00$ down and monthly payments of $\$ 100.00$. He has apparently inade no payments after the initial down payment, and we have sent a routme demand letter seeking immediate full payment and the usual additional costs and fees.

Market research revealed that consumers are more likely to purchase software if offered the opportunity to buy a home computer at the same tinie. Because ESM manufactures only software, it purchases computer equipment from wholesalers to accompany its software package. The price for the computer is a inarkup of about $150 \%$ over cost-a reasonable markup in the industry considering that ESM doesn't make its own computers, but purchases them for resale to consumers. The software is marked up by more than $200 \%$. Although this may seem high, it is common in the industry because the cost of the materials constituting software (a bit of plastic and paper) is minimal; the increase compensates the creativity of those who invented the program. These prices are about fifty percent higher than comparable materials in discount apphiance stores, but no store carries programs exactly like those developed by ESM.

The file also contains a meinorandum from one of ESM's telephone collectors, reporting a conversation with White, in which he said something about having been proinised a television set by the salesperson. Sometimes the company's salespersons, who are independent contractors, piggy-back their own side-deals onto a sale for ESM. The company's position is that these sales are separate transactions that involve other parties; ESM cannot afford to take responsibility for them.

ESM sent White the usual collection notices, including a warning of possible suit, and telephoned him twice at home and twice at work. $\mathrm{He}$ expressed a desire to cancel the sale during one of these conversations, 
but he did not try to cancel within the three days allowed under state law and the contract.

\section{B. Memorandum to File, from Counsel for Randy White}

Randy White, who seems rather timid and speaks quietly, currently works as a fast-food cook at a local Pizza King, with take-home pay of about $\$ 132.00$ per week. At the time of the purported purchase that gave rise to the current matter, however, he was employed as a die stamper at a local plastics factory, taking home approximately $\$ 398.00$ per week. White and several hundred other employees were laid off from that job shortly after the alleged purchase. White expects to be rehired, but does not know when that might be.

White has one child, Jerry, age 12 . One evening about six months ago, a man rang his doorbell. He turned out to be a salesman, and he sold White a personal computer and a set of educational programs for use in the coinputer. White doesn't remember all the details of their conversation. He introduced himself as Steve; if he gave a last name, White doesn't remember it. He was about thirty, energetic and very convincing. He said that he hived a few blocks from White. He started the conversation by saying that one of White's neighbors (he may not have said which one) had told him that White had a child in school. He had coine to commiserate about the poor quality of the local elementary school; he had a child in the school system himself, and he knew how things were. But he also had come because he had discovered a marvelous way to improve his own daughter's education and to help her get aliead in school. He had bought a computer and learning programs for her about a year ago, and her grades had improved significantly.

White had been increasingly worried about Jerry, who was doing very poorly in school. Steve seemed very concerned about Jerry. They continued to talk in White's living room, and White made Steve some coffee. White has only a sixth-grade education and believes that this is the reason, as he puts it, "wliy I've never gotten aliead." This is also a reason why he very much wants Jerry to do well in school.

Steve showed White brochures about the software, and the programs looked very attractive, full of engaging color pictures and graphs. Steve had a number of advertising folders, describing the full set of five programs-one each to teach math, reading, spelling, and history, and a game program called "Stellar Avenger." (White no longer has the brochures and doesn't remember whether Steve left them.)

Steve said that he was so impressed with the educational software and how it had helped his daughter that he was going around the neighborhood telling other people about it. Steve said that the software was 
very simple - that any kid who could play a video game could learn to use it. White could get a set for Jerry to use, plus the computer, keyboard and monitor, with only $\$ 250.00$ down. Steve was certain that Jerry's grades wonld improve. The payments would be only $\$ 100.00$ a month.

Our client remembers Steve saying that he could change his mind and cancel the contract. However, when I pressed for details, White could not remember Steve's exact words. Another thing White remembers-it was the final thing that clinched the sale-was Steve saying that, if he signed the contract and gave him an extra $\$ 100.00$ in cash (which White did), he'd provide White with a small color portable television.

Eventually, our chent agreed to buy. Steve filled in contract form that White signed. He gave White a copy of the contract. White says that he began to read the contract, but realized that he could not understand it, and just signed it.

About two weeks later, Steve came back with big cartons, containing the personal computer and software. This time he was im a rush, and they didn't talk or have coffee. He said that he was sorry, but the television company had stopped making the portable televisions, and he'd have to refund the $\$ 100.00$. White told him that the television was one of the mam reasons that White agreed to buy. "I told him that we really wanted that TV," our chent said. "I refused to take the hundred dollars back." Steve said he'd see what he could do, but White has never seen or talked to him simce, and doesn't know where to reach him.

For a few days, Jerry occasionally fiddled with the computer. White urged him to read the instructions so he could make real use of the software, but he said he couldn't understand them and preferred to watch television. He did play Stellar Avenger a few times but quickly got bored. After a nonth had passed, it was clear that Jerry wasn't going to learn how to use the educational programs, and he'd even stopped playing the video games.

At about this time, White was laid off from the plastics factory. With Jerry not using the software and the family squeezed financially, he decided to cancel the contract. So he didn't make any payments, though bills came in the mail. Within a few weeks a Ms. Parker from the coinpany's collection department called to ask when White was going to make payments. He told her that he had decided to cancel and that she could come get the equipment. "She said that I couldn't do that and that I'd signed a contract and would have to pay."

Once, Ms. Parker called White at work. This frightened him, because Pizza King forbids personal telephone calls at work, and White's boss answered the phone. During that call, White told Ms. Parker about 
Pizza King's prohibition on such calls, but the boss was nevertheless furious. White was afraid of losing his job, and therefore sent the company a cash payment of $\$ 100.00$ a few days later. Since then, he has made no payments, and White recently received a letter from lawyers for ESM, demanding full payment of the balance due and threatening to seek court costs, interest, and counsel fees in the event of hitigation.

\section{The Questions Presented}

I propose now to look at the transactions described in the preceding memoranda, not as an occasion for the consideration of disputed questions of law, but as a set of relations among five people-Dorothy Smith, Joseph Small, Pat Stone, Steve Clark, and Randy White ${ }^{8}$-and ask:

First, what do you see when you observe these interactions?

Second, in hight of what you see, what should be the function of the law in channeling relationships such as these?

Third, in light of your answer to that question, what should be the function of lawyers in representing participants in such interactions?

As noted mitially, I propose to describe the varying answers given to these questions as aspects of what I will call conservative, liberal, and radical perspectives. My assertion is that the several ingredients of one perspective tend to co-exist in an individual's mind, that they are mutually reinforcing, that they form a reasonably coherent view of the world. In what follows, I do not attempt to prove the truth of this assertion, whether empirically (by polling some representative set of legal actors) or philosophically (by demonstrating analytically that the several imgredients are linked logically). I do not ask whether you can justifiably not beheve the truth of what I describe; rather, I ask whether you do beheve it, whether you recognize it as consonant with your experience. As James Boyd White has put it:

I invite the reader to check what I say against what he or she knows ... Rather than making a case that is meant to stand or fall by the degree to which the unwilling are compelled to assent to it,...I inean to present a set of reflections ... to be tested against the reader's own. ${ }^{9}$

8. Randy White's wife and son, Ms. Parker, and the Pizza King manager also are persons involved in this story (as are other, wholly anonymous, employees of ESM, Pizza King, and the manufacturers and distributors of the computer equipment in question). In what follows $I$ will be only slightly free of the tendency of the law to regard them as complete outsiders to the transactions in question. See infra note 40 and accompanying text.

9. White, Economics and Law: Two Cultures in Tension, 54 TENN. L. Rev. 161, 167 (1986). The prevailing approach to knowledge tends to equate the forms of logical inference (whether from data or argument) with persuasiveness and academic respectability. I question not the utility of that approach, but only the claim of exclusive validity that is sometimes made for it. 
I begin with the conservative perspective because I believe that it is the "default" perspective of our legal system; it was embraced wholeheartedly by the architects of nineteenth century common law development, and it is still widely supported im our legal and pohtical practice. The hiberal perspective contends with the conservative for major mput into current legal regulation, but the legal world is, in my view, more accurately described as a partial lamination of the liberal onto the conservative perspective than a clear acceptance of one or the other. ${ }^{10}$ The radical perspective has almost never manifested itself in legal regulation, or otherwise achieved wide acceptance.

\section{Perspectives on INequality}

\section{A. The Conservative Perspective}

In the problem set forth above, a conservative perspective sees five people doing the world's work. Each motivated by self-interest, they all seek to accomphish things that will be achievable, and whose consequences will be socially beneficial, if and only if the product imvolved meets people's needs as they choose to define them. A self-regulating market interacts with self-regarding, competitive people to produce a division of labor and of responsibility that will maximize the ability of the product to estabhish itself.

It is the self-interest of Sinall and Smith, a teacher and a programmer with the knowledge and skill to generate a potentially useful product, that permits them to actualize whatever altruism may be part of their motivation for creating ESM. Smith and Small need Stone in order to act on their motivation. In the enterprise that they have formed, Smith and Small are not primarily responsible for its profitability; that is Stone's responsibility. The corporation they form, ESM, in turn needs Clark if it is to turn its productive capacity into sales and profits, while he needs them in order to have something to sell.

The instrumental, even mamipnlative, quality of human relations evidenced in the problem is not a significant negative element. It is simply a fact of life, apphed here (as it often is) in ways that enhance efficiency. White is in this respect no different from the others. His motive is family self-imterest, success defined in competitive terms-first, in his child's schooling and then, presumably in the labor market. More particularly, his motivation in his interaction with Clark and ESM is to get a "good

10. Political power in the tangible sense is only a partial explanation of that circumstance. To some extent, the explanation is embedded in the liberal perspective itself, which is a lamination onto a conservative perspective of inputs that are inconsistent with it, rather than a wholly different world-view. See infra text accompanying notes 24-30. 
deal." And Clark's attitude and conduct toward White, although perhaps a bit tacky to soine tastes, differs only in style from that of any of the ESM people toward one another, or toward him.

From a conservative perspective, it is socially beneficial that people who assert themselves, and do so effectively, do better than those who do not. If White is forced to keep and pay for the software, he might in fact end up inducing his child to use it. He is likely to be better off in the long run if he is held responsible for his actions than otherwise, and, in any event, it is more respectful of his autonoiny (and his privacy) to regard him as responsible for his actions than to seek to protect him in soine way froin Clark's manipulations.

In responding this way, a conservative perspective presents human decisionmaking as a relatively uncoinplicated response to "incentives." 11 People seek (for all practical purposes, endlessly so) to maximize their wealth; the world is most saliently described as a place of scarcity, in which no one can wholly satisfy his or her einergent "needs," and few can come close to doing so. Adversity and deprivation are goads to achieveinent; protection is an induceinent to lassitude. Huinan interaction is a relatively impersonal process, and judgments about the consequences of legal rules are inade with substantial confidence. The law, too, acts toward people in an impersonal manner: When it declines to intervene in private bargaining (other than to hold people to their barganis), it is acting out of respect for autonoiny and privacy; when the law finds it justified to intervene, it does so paternalistically, rather than out of compassion or einpathy.

A so-called "imbalance" in bargaining power is not problematic, but rather an essential aspect of freedom. None of the actors is legally bound to deal with any other. They all make choices in light of their circuinstances, to inaximize their individual gain. All five people in the problein are running the race of life. This is all to the good, for it produces extra effort from soine people, which redounds to society's benefit. Clark is selling software door-to-door; he is not selling Cadillacs, or Fortune 500 corporations (yet), and he will not graduate to that level simply because he can "fast talk" an anxious and undereducated parent.

That soine do better than others-indeed, that some do quite poorly-is also not problematic, because it is the differences in talents, motivation, and ability of people that inake for a inore productive world. All five people involved are, and should be, equal in their legal right to

11. Consider Judge Richard Posner's paradigmatic statement of this approach: "The concept of man as a rational maximizer of his self-imterest implies that people respond to incentives-that if a person's surroundings change in such a way that he could mcrease his satisfactions by altering his behavior, he will do so." R. POSNER, ECONOMIC ANALYSIS OF LAw 4 (3d ed. 1986). 
try to get ahead in a coinpetitive world. A modern conservative perspective rejects a hereditary aristocracy, an established church, a racial caste system, or other legally-imposed disabilities based on status. It is, however, relatively slow to see current inequalities of condition as reflecting earlier inequahity of such sorts. Rather, it tends to attribute inequality to differences in the abilities of people, including the ability to overcome obstacles of one variety or another. The conservative perspective is perforce even more reluctant to view as problesnatic inequalities reflecting prior inequalities merely of wealth.

There is therefore no expectation, froin a conservative perspective, that the absence of legal constraints on the ability of each to succeed in that effort will produce relatively equal degrees of suceess. People are thought to differ widely in their possession of the qualities that inake for success; by rewarding those who have thein, a market-oriented systein maximizes utility. ${ }^{12}$

This world-view lends great presumptive legitimacy to the structures and actions of those who exercise private and public power over "ordinary" people. The premises are that in most instances those in authority had good reason to act as they did and that it is socially beneficial in particular instances to uphold rather than to undermine their authority. Individuals with the necessary talent and drive will generally prove able to rise in the social order, and thereby exercise greater discretion with respect to their own hives; those lacking those quahties will justly reinain among those more governed than governing. The classic expression is that of St. Paul: "The powers that be are ordained of God . . . Therefore, ye inust be subject, not for wrath, but for conscience's sake."13

12. James Feninore Cooper's essay, "On Station," is a classic expression of this consciousness, worth reading in full. Consider the following excerpt:

As a principle, ... in those states where slavery does not exist, all men have essentially the same rights, an equality, which, so far fron establishing that "one inan is as good as another," in a social sense, is the very means of producing the inequality of condition that actually exists. By possessing the same rights to exercise their respective faculties, the active and frugal becoine inore wealthy than the idle and dissolute; the wise and gifted more trusted than the silly and ignorant; the pohshed and refined more respected and sought, than the rude and vulgar.

In nuost countries, birth is a principal source of social distinction, society being divided into castes, the noble having an hereditary claim to be the superior of the plebeian. This is an unwise and an arbitrary distinction that has led to nuost of the social diseases of the old world, and from which America is happily exenupt. ...

It is a natural consequence of the rights of property and of the sentiment named, that birth should produce sonie advantages, in a social sense, even in the most deinocratieal of the American conmunities. The son inubibes a portion of the intelligence, refinenient and habits of the father, and he shares in his associations. These must be enumerated as the legitimate advantages of birth.

J.F. COOPER, THE AMERICAN DEMOCRAT 77-78, 80 (1956).

13. Romans 13:1-5. 
As for the specific legal question of "unconscionability" or a similar objection to holding White to his bargain, neither Clark's selling tactics nor the terms of the ESM contract presents a serious problem. In the long run, ESM simply cannot succeed unless buyers want the product, that is, find it useful to them, and can pay for it. Short-term success by high pressure salespeople, aimed at people unable to pay or unmotivated to pay by reason of the disutility of the product to them, will produce a rising default rate, which, in turn, will either induce the company to change its sales tactics or its products or tend to cause the company to fail altogether. By the same token, "consuiner protection" laws cannot succeed in protecting consumers by forcing producers to abandon practices that are efficient. They will at most "succeed" in driving entrepreneurs out of a particular segment of the market. It is no inore possible than it is desirable to protect people from the inarket.

The role of the law from this perspective is to facilitate consensual relations. Small, Smith, and Stone come together as they wish. ESM is their creature, shaped as they have chosen. The decisions, for example, to form a corporation as a vehicle for their activities; to buy computers for resale, rather than to manufacture or sell them as brokers for others; and to use salespeople as independent contractors rather than employees, are choices that they make, and to which the law gives effect. The law of corporations, agency, sales, and employment relations are all aspects of the law of contracts: They all rest on the basic proposition that people are free to agrec as they choose, and the role of the law is to bind them to that agreement. No one is protected from another unless he or she seeks and obtams protection by agreement. Shareholders agreements, sales contracts, the contract of hire of a salesperson, are all imstances in which people channel their own relations, and decide how important it is to them to seek particular protections. The law is indifferent to outcomes, but not to the binding quality of agreements. ${ }^{14}$

To be sure, certain limits are implied by the premises of the conservative perspective. To view contracting as an act of choice presumes the existence of a choice. However, it is central to a conservative perspective that such a limit be a narrow one, because a "free" choice is one made in tight of the constraints imposed by one's circumstances in life.

14. "Binding" only in the normative sense. The remedial inadequacies of the law are themselves simply data to be taken into account by the parties in structuring the protections that they choose to seek from one another. The posting of bonds, provisions for liquidated damages or specific performance, and the personal guarantees of shareholders otherwise not liable for corporate debts are examples of the ways im which individuals dissatisfied with the remedial processes of the law can contract to obtain heightened protection for themselves. 
That thought has been no more eloquently stated than in Mr. Justice Pitney's opinion for the Supreme Court in Coppage v. Kansas:

No doubt, wherever the right of private property exist, there must and will be mequalities of fortune; and thus it naturally happens that parties negotiating about a contract are not equally unhampered by circumstances. ... Indeed a little reflection will show that wherever the right of private property and the right of free contract co-exist, each party when contracting is mevitably more or less influenced by the question whetler he has much property, or hittle, or none; for the contract is made to the very end that eacli may gain something that he needs or desires more urgently than that which he proposes to give in excliange. And, since it is self-evident that, unless all things are held in common, some persons must lave more property than others, it is from the nature of things impossible to uphold freedom of contract and the right of private property without at the same tine recognizing as legitimate those inequalities of fortune that are the necessary result of the exercise of those rights. ${ }^{15}$

A conservative perspective acknowledges that soine people are disabled from contracting by reason of lack of free choice. But the limitation of this concept to designated categories of individuals (children, sailors, and unarried women were the traditional "protected" groups) and the narrow scope given to the law of undue influence, duress, and fraud reflect the cabining effect of the premise that people should look out for themselves. Randy White is a free adult; like the employee in Coppage, he is "in all respects competent, and at liberty to choose what was best from the standpoint of his own interest."16 The fact that he has little education, a poor self-concept, very hittle ability to understand or influence his child's educational status, and an excess of creduhty in his dealings with the Stephen Clarks of this world, does not set him apart from millions like him who tend to be less than optinially successful in their negotiations with others.

A conservative perspective looks especially askance at himitations on the enforcement of contracts that impose transaction costs on enterprise. It is not a coincidence, therefore, that the traditional disabilities apply to categories of people that are relatively easily discerned at a glance. So, for example, a jeweler knows that he or she may run into difficulty selling an expensive watch or ring on credit to an adolescent, and it is not a serious burden on enterprise to mipose that disappointment of expectations or the cost of verification of age. It is another matter entirely to tolerate a concept of "equality of bargaining power," or a concept of

15. 236 U.S. 1, 17 (1911).

16. Id. at 9 . 
"abusive" or "harassing" collection practices, that permits almost anyone to inake a litigable challenge to an atteinpt to enforce a contract. ${ }^{17}$

A somewhat different, but equally fundamental, function of law from a conservative perspective is to celebrate the legitimacy of the prevailing social order. It does this by valuing the norm of due process in the basic sense of a "day in court" - the traditional assurances of impartial adjudication-and by at the same time disvaluing substantive or procedural doctrimes that rest on substantial concern about the substantive "fairness" with which individuals have treated one another. A judicial decree enforcing a contract is a renewal of the profession of faith that it is just for people to be held to their agreements, and that it is the justice of the claim, and not simply the power of the creditor, that occasions the marshalling of public force to support it. ${ }^{18}$

The foregoing characteristics of a conservative perspeetive in large measure shape the response to the question of what the role of lawyers should be. It is important to keep in mind that, in our post-mercantilist world, a conservative perspective regards people as equal before the law, and therefore as equally entitled to seek and obtain representation. In that sense, it is not problematic that Randy White can resist collection efforts through titigation. However, a conservative perspective views representation as a cominodity like any other. The same factors that have led White to be relatively unable to buy what he may want in the world also limit his ability to obtain the legal representation that he might want. Indeed, that lack of access to legal representation - that is, the fact that representation has a cost, which can be paid only by foregoing other expenditures that may not be regarded as discretionary by one in White's circumstances-is a large element in keeping the social cost of the ability to resist contract claims within acceptable bounds. In approaching the question of the societal value of subsidizing legal representation, therefore, wholly apart froin any question of the ethical justification for the expenditure of public funds for White's benefit, a conservative perspective is concerned that the readier availability of legal representation will

17. To this effect, see Epstein, Unconscionability: A Critical Reappraisal, 18 J.L. \& EcoN. 293 (1975), arguing for rules that identify broad classes of individuals "not requiring case-by-case analysis," and allowing sellers to "steer clear of contractual arrangeinents" with protected individuals. Id. at 300 .

18. Richard Abel, viewing this question from a radical perspective, suggests that "the legitiinacy of the law ... has greater meaning for the overprivileged who invoke it than for the underprivileged in whose name it is invoked." Abel, From the Editor, 12 LAw \& Soc'Y REV. 189, 197 (1978). Richard Epstein lends unintended weight to this perception by closing his essay on unconscionability with a century-old judicial pronouncement that, "if there is one thing which more than author public policy requires, it is that ... contracts when entered into freely and voluntarily shall be held sacred ...." Epstein, supra note 17, at 315 . 
augment transaction costs. A rising default rate that burdens ESM's profits is unexceptionable if it comes from the relative dissatisfaction of customers or from imprudent practices in permitting eager entrepreneurs like Clark to extend credit to those likely to default. But a requirement that ESM spend substantially more money to collect its debts, simply because it becomes easier for its debtors to resist demands for payment, is another matter entirely. From a conservative perspective, therefore, access to legal services, and to court, is a norm that quickly comes to seem problematic. ${ }^{19}$ This perception apphies to the shaping of procedural law so as to enhance or diminish disincentives to higation, and to the question of the social utility of adversarial representation by counsel for either side, as much as the question of subsidized legal representation of consumers such as White. It explains the apparent one-sidedness of a conservative response to questions of "access": It is far more likely to be socially useful for creditors to have ready access to litigation than it is for debtors; what to others may seen an oppressive "mill" 20 is froin a conservative perspective a socially beneficial reduction in transaction costs.

\section{B. The Liberal Perspective}

The major differences between a conservative and a liberal perspective have their origin, I believe, in two related factors. First, one who views the world from a liberal perspective has a substantial concern about substantive inequality. Percciving inequality as self-reinforcing, he or she is more disturbed than is a conservative by its status-linked sources. From a liberal perspective, the contimuing effects of historic patterns of inequality now conceded to be unjustified are far more likely sources of actual current inequalities of condition. Beyond that, pronounced deprivation, whatever its source, is seen as a barrier, and not simply as a goad, to social mobility.

Second, a liberal perspective, being conscious of social consequences that it deems harmful rather than berign, is more likely to perceive abuses in the exercise of power, which it regards as casting a shadow on the legitimacy of the prevailing social order. It is consequently more likely to view the powerful as equally subject to the vices of "human

19. Judge Posner, for example, rather breezily asserts that the "flood" of fee-shifting statutes "overencourage[s] litigation." Posner, The Decline of Law as an Autonomous Discipline: 1962-87, 100 HARV. L. REv. 761, 770-71 (1987).

20. The classic work, written by Bea Moulton while she was a law student, is Note, The Persecution and Intimidation of the Law-Income Litigant as Performed by the Small Claims Court in California, 21 STAN. L. REv. 1657 (1969). 
frailty" as are the multitudes. ${ }^{21}$ It is Lord Acton, rather than St. Paul, who supphies the salient imsight. ${ }^{22}$

In these ways, a liberal perspective manifests a more complex understanding of human actions than does a conservative perspective. It is dubious about the sufficiency of an "mcentives" approach to human motivation; ${ }^{23}$ wary about the presumption that the rationality of the powerful will suffice to limit abuses; and ambivalent about the degree of detachment and impersonality with which legal actors should view the lives of people whose hives are affected by law. ${ }^{24}$

Dubiety, wariness, and ambivalence suggest partial, limited acceptance. The hiberal stance toward White is one of detached sympathy; it is careful not to judge limı unfairly, but if it can do so fairly, it will judge him. To the extent that judgment and empathy are inconsistent qualities, a hiberal perspective seeks to incorporate its empathy imto the substance of its judgment as much as it can, and will then let judgment have the last word.

Laminating "regulation" onto "facilitation," a liberal perspective seeks to limit "abuses" that will mevitably occur in unregulated human interactions. More concerned than the conservative perspective for the seriousness of those abuses, and beheving them less uncommon, the hiberal perspective regards it a major function of the law to bring those abuses withm tolerable himits; the purposes of doing so are to protect persons from abuse and to make the market economy justifiably legitimate. In that latter respect, it is similar to a conservative perspective im wanting the legal system to play a legitimizing role, but different im perceiving that the extent and consequences of substantive mequahty counsel a significant degree of redress before its legitimacy can be comfortably celebrated.

A liberal perspective is therefore willing, indeed finds it important, to impose costs on transactions where the imposition discourages harmful consequences. The law of unconscionability and other "reforms" in the law of commercial transactions (i.e., the inandatory three-day cancellation period and the abolition of the "holder in due course" doctrine) are hospitably viewed as an appropriate response to expectable instances

21. "Man's capacity for justice makes democracy possible; but man's inclination to mjustice makes democracy necessary." R. NEIBUHR, THE CHILDREN OF LIGHT AND THE CHILDREN OF DARKNESS xi (1944).

22. "Power tends to corrupt, and absolute power corrupts absolutely." J. DALBERG-AcroN, ESSAYS ON FREEDOM AND POWER 364 (G. Himmelfarb ed. 1948).

23. See supra note 11 and accompanying text.

24. Judge Patricia Wald's and Dean Mark Yudof's responses to Jack Getman's plea for the legitimacy of "human voice" in legal discourse are illuminating in this respect. See Colloquy: Human Voice in Legal Discourse, 66 TEX. L. REv. 577, 589, 623 (1988). 
of overreaching. The consequent increase in transaction costs is not viewed as harmful.

A liberal perspective essentially accepts the value of an instrumental market-oriented approacl to human interaction, but does not axiomatically prefer a self-regulating market to one subjected to some significant degrec of legal control. Like the conservative perspective, it sees Randy White as an individual making rational, self-regarding cloices, for which lie is responsible, so long as the law has given him an adequate chance to obtain and to process the information that lie needs in order to bring his powers of rational clioice to bear on his decisionmaking. The notion of "informed consent" is a powerfully attractive one to a liberal perspective; mandatory disclosure rules at the point of sale, restraints on deceptive or overbearing selling practices, and "large type" or "plain Englisli" requirements are exainples of measures viewed as not only justifiable, but efficacious. The underlying assnmption is that Randy White will know about, and will act on, the advantages that consumer protection law provide him.

A liberal perspective struggles to redefine efficiency to require a coinpany like ESM to internalize more of the cost of its enterprise. For this reason, it does not treat increases in transaction costs that arise from the law of unconscionability, for exanple, as per se "inefficient." Overall, a inajor objective of the liberal perspective is to enhance public awareness of the social costs of enterprise, and to discourage attempts by enterprise to externalize tliein. Faced witl a choice betwecn the concrete reality of human sufferimg not confidently deemed just, and the abstract calculation of incentives that arguably suggests an increased aggregate long-term gain if some significant suffering remains unalleviated, ${ }^{25}$ a liberal perspective will find sure bases for clioice in its preference for practicality over doctrimal purity and its strong concern with injustice.

A liberal perspective also does not fully accept the sufficiency of the public-private distinction, so powerfully suggested by Justice Pitney's analysis, which defines coercion simply as interference by goverument in private transactions and defines as an aspect of freedoin interference by other private actors in one's attempts to achieve one's goals. ${ }^{26}$ From a liberal perspective, a characterization by which White's freedom is not

25. Cf. supra text accompanying note 11.

26. Coppage v. Kansas, 236 U.S. I (1914), is unreservedly clear on this point:

[T]he term "coerce" [cannot be applied] to the mere insistence by the employer, or its agent, upon its right to prescribe terms upon which alone it would consent to a continuance of the relationship of employer and employé. ... [T] here is nothing to show that Hedges [the employee] was subjected to the least pressure or influence, or that he was not a free agent, in all respects competent, and at liberty to choose what was best from the standpoint of his own interests. Of course, if [the employer] ... was otherwise within his legal rights in insisting that Hedges should elect whether to remain [an employee] or to retain 
impaired by Clark and ESM, but ESM's freedom is impaired by the UCC is deeply problematic.

Many of the premises of a conservative perspective, however, are not rejected by a hiberal perspective. First, I beheve that the liberal perspective accepts the fundamental principle that values are inherently subjective and arbitrary, with the imphcation that they can justifiably be brought into human interaction only through contract. ${ }^{27}$ It does this not so much for philosophical reasons as out of a perceived compulsion of the lessons of history: The liberating consequences of the echipse of feudalism, the divine right of kings, and the hegemony of the Umiversal Cliurch, and (most powerfully in our lifetimes) the terrifying experience of twentietli-century totalitarianism. ${ }^{28}$ Second, impaled as it is between polar paradigms of human relations-tlie conservative view of people as essentially competitive and instrumental in their dealings witll one anotlier, and the radical perception of people as essentially cooperative and inutually responsible (but for the false consciousness generated by an unjust social order) ${ }^{29}$-a liberal perspeetive shrinks froin the utopianisin and the tendency toward Jacobimism of the radical perspeetive and, lacking a theoretical basis to reject conservative premises, sees no alternative to acknowledging their trutll.

Conservative ideas are accepted, then, out of a feeling of unpalatable necessity, rather than embraced wholeheartedly. Moreover, the hberal perspeetive does not accept the policy implications of conservatisin. But, whetller the einbrace is grudging or gleeful, the de facto acceptance by a liberal perspective of the most fundamental philosophical presuppositions of the conservative undermines liberal efforts to redefine efficiency to require very substantial internalization of the social costs of enterprise, and to view private power as a threat to freedoin and not merely a inanifestation of it. This fundamental dilemma is, in iny judgment, the source of the ambivalence and apparent "mushiness" of liberal interventions,

his membership in the union, that insistence is not rendered unlawful by the fact that the choice involved a pecuniary sacrifice to Hedges.

....

... Included in the right of personal hiberty and the right of private property-partaking of the nature of each-is the right to make contracts for the acquisition of property.... If this right be struck down or arbitrarily interfered with, there is a substantial impairment of hiberty in the long-established constitutional sense.

Id. at $8-9,14$.

27. See West, Taking Preferences Seriously, 64 TuL. L. REv. 659, 666-68 (1990).

28. Compare Kenneth Penegar's conclusion, regarding what he terms "the possibility of communal," as distinguished from subjective, "value": "Constructing this theory is not as difficult as giving force to it because of our own cultural historical experience ...." Penegar, The Five Pillars of Professionalism, 49 U. PITT. L. REv. 309, 385 (1988).

29. For the conservative view, see supra text at pp. $420-421$, and, for the radical perception, see infra text at p. 431. 
many of which can readily appear more like ad hoc exceptions-born of mere sympathy for those suffering concrete and immediate (albeit perhaps at times short-run) harms, or attributable to political pressuresthan principled rejections of conservative doctrine. ${ }^{30}$

Within the liberal perspective, lawyers play a positive role in the systein, and are admitted as players less cautiously than by the conservative perspective. The presence of advocates on behalf of consumers such as White is important as a way to police the market and thereby minimize abuses that are seen as something more than occasional. The responsiveness of litigation to such claims is a major social value. So, liberals generally support such devices as discovery, fee-shifting legislation, and other ways that make legal representation more available. They experience soine discomfort over the presence of "counter-abuses," by which undeserving debtors, for example, are able to take advantage of inechamisms designed to protect worthier consumers, and tend therefore to have to struggle to avoid the polar hazards of paternalisin and "irresponsible" client-orientation in the representation of debtors.

Froin a liberal perspective, there also is social value in the presence of legal representation on behalf of ESM. The attorney-counselor, cognizant of the conflict between the company's short- and long-tern interests and acting as the voice of the law to the chent, plays a constructive role. Liberals struggle (sometimes unsuccessfully) not to over-estimate the extent to which counsel in fact play this role, and are generally sympathetic to atteinpts to moderate the "excesses" of the adversarial consciousness, which inarginalizes or even delegitimizes such a role. The same ambivalence that is present from a liberal perspective about the self-regarding, competitive nature of commercial interactions is present with respect to the attorney-chient relation.

More broadly, a liberal perspective recognizes-albeit a bit sotto voce-that a commercial system based on mass credit requires that relatively adequate remedies be available to creditors, to prevent the rise of counter-abuses on the part of purchaser-debtors. Thus, on both sides, the role of counsel is a socially useful one, to be encouraged by legal regulation of the profession, as long as attorneys for each side approach their task with an attitude that is not ferociously chent-oriented. In this area, as in others, the liberal behef that celebration is warranted only if certain requisites are met is caught in recurrent ambivalence between faith and skepticism over the question whether they are being inet. To

30. Justice Scalia, for example, dissenting in Johnson v. Transportation Agency, 480 U.S. 616, 677 (1987), characterizes judicial receptivity to affirmative action as unlikely to be "displeasing to pohtically elected officials, to whoin it provides the means of quickly accommodating the deinands of organized groups." 
the extent it leans toward faith, the liberal perspective tends to lose its differentiation from the conservative. To the extent it leans toward skepticism, it finds itself challenged by the unrejected underlying premises of conservativism.

\section{The Radical Perspective}

A radical perspective differs at the outset from a liberal perspective by directly addressing and rejecting the premises of the conservative perspective. In place of a world in which each of us is responsible for himself or herself, a radical perspective sees a world in which we are to a significant degree responsible for each other; it sees people as linked as well as separate, and deems the systematic empliasis on separateness as the product of social organization, rather than as innate. It regards a sense of reciprocal responsibility as a value that is innate-in the sense of being an authentic aspect of personhood-even if not often recoverable in the consciousness of individuals.

A radical perspective does not accord existing allocations of status the ethical presumptive validity that both conservative and liberal perspectives give them (albeit to significantly differing extents) in justifying outcoines. First, it sees the market as largely reflecting prior allocations lacking norinative significance. Contrast, for example, with the view of Mr. Justice Pitney that of the eighteenth-century Quaker, John Woolman:

By the agreements and contracts of our predecessors, and by our own doings, some enjoy a much greater share of this world than others; and while those possessions are faithfully improved for the good of the whole, it agrees with equity; but he who, with a view to self-exaltation, causeth some to labor immoderately, and with the profits arising therefrom employs others in the luxuries of life, acts contrary to the gracious designs of Him who is the owner of the earth; nor can any possessions, either acquired or derived from ancestors, justify such conduct. Goodness remains to be goodness, and the direction of pure wisdom is obligatory on all reasonable creatures. ${ }^{31}$

Second, a radical perspective sees "preferences" as strongly channeled by the market. As Cass Sunstein put it:

Preferences are heavily influenced by context, including one's position in the social order. That position is in turn influenced by legal rules. ... [Therefore,] the rules and the regime cannot be justified, without circularity, by reference to the preferences. This conclusion has important implications for the assumption ... that the role of law is to facilitate the satisfaction of private preferences....

31. J. Woolman, $A$ Plea for the Poor, in The Journal of John Woolman and A Plea for THE POOR 226 (1961). 
[T] he fact that people are content with the status quo need not be a dispositive argument against changing it. One of the functions of politics is to expose adaptive preferences as such, and to subject the existing legal regime to critical scrutiny even if people have adapted to it. $^{32}$

More fundamentally, a radical perspective views the market as both a manifestation and a source of false consciousness, which objectifies human beings, impoverishes people spiritually and materially, and fosters an imstrumental approach to one another that is then sought to be justified as "just human nature."33

A radical perspective proceeds as well from a fundamentally different stance toward inequality. The "fact" of noticeable differences in lifesituation-imcluding apparent talents and abilities as well as status and material success-is not regarded as "natural" or presumptively justifiable, but as a profound reproach to the social order. Differences in talents and abilities are not regarded as axiomatically justifiable bases of preference. ${ }^{34}$ One source of this reluctance is the perception that much of the "talent" that facilitates success in the world is morally probleinatic. ${ }^{35}$ Another is a deep-seated skepticism whether apparent differences in talents and abilities are the cause as much as they are the consequence of inequalities of status, wcalth, and power. This skepticism can have a religious or a secular manifestation. A rehious manifestation proceeds from the perception of the common humamity of all persons, proceeding from their common divine paternity, as the most salient fact about one another. The Quaker precept, to seek to answer "that of God" in every person, is to me a profound expression of the behief in the potential of

32. Sunstein, Two Faces of Liberalism, 41 U. MIAMI L. REv. 245, 248-49 (1986).

33. Both the conservative and the radical perspectives regard their differing views about individual and reciprocal responsibility as reflecting the way that human nature "rcally is," at the same time as they believe that social ordering consistent with their view is socially beneficial; consequentialist and ontological approaches reinforce one another in both cases.

34. Coinpare Lloyd Weinreb's description of the differing ways in which one draws the "boundary between a person and the contingent circumstances of his existence." Using John Rawls and Robert Nozick as representative of polar examples of this effort, Weinreb suggests that their theories of justice "reach largely contrary conclusions . . . because they rest on fundamentally opposed boundary assumptions." He continues: "Rawls assumes that none of a persons's attributes is constitutive; all are fortuitous and undeserved. For that reason, all differential characteristics, even ones like intelligence and talent, are treated as social goods, which themselves or the fruits of which are to be used for the benefit of all." L. WeINREB, NATURAL LAW AND Justice 236-38 (1987).

35. Note, for example, Socrates' judgment that success soinetimes attends those with "a shrewd and bold spirit together with a natural aptitude for dealing with inen." The "talent" that such occupations call upon, he terıned "pandering." PLATo, Gorgias 44 (Hamilton trans. 1960). The early twentieth-century British philosopher, L.T. Hobhouse, attributed a significant portion of a person's inaterial success to the "talent" of a "special skill in bargaining," which he characterized as a "rather antisocial" quality, not adding to "social wcalth." "As accruing to the individual it represents a tax on others." L. Hobhouse, The Elements of Social Justice 170 (1922). 
each person for the realization of qualities not readily visible. ${ }^{36}$ A secular manifestation tends to emphasize the waste, the betrayal, of the potential achievement that attends status hierarchies such as race, gender, and class; it sees a world of "mute inglorious Milton[s]" in ghettos and prisons, im schools for people destined (like Randy White's child) to fail, and in many of the jobs that make up our economy. ${ }^{37}$

Complementing and reinforcing this view is a deep-seated identification with those lacking the traditional indicia of worldly success. The most profound religious expression of this identification of which I am aware is Matthew's prophecy of the sheep and the goats, in which the Evangehist tells how God will one day judge the nations according to

36. Compare the words of the Catholic monk, Thomas Merton: "[H]uman nature, identical in all men, was assumed by [God] in the Incarnation . . . . Consequently we have the obligation to treat every other man as Christ Himself, respecting his life as if it were the life of Christ." T. MERTON, The Nonviolent Alternative 112 (Zahn rev. ed. 1980). Consider too this Talmudic explanation of the significance of the Creation account:

Therefore was a single man

only [first] created to teach

thee that if anyone destroy

a single sonl from the children of man, Scripture

cliarges him as though he

had destroyed a wliole world,

and whoever rescues a

single soul from the children

of inan, Scripture credits

him as though lie liad saved a whole world.

IV Mishnah, ORDER NEZIKIN, TRACTATE SANHEDRIN 5 (A. Blackman trans. 2d ed. 1963) (brackets in original).

37. The desire of the editors of the Joumal for a citation to the source of the quoted words led me to read again Gray's Elegy, and I found the forgotten surroundings of those few remembered words so graphically "on point" (even though "secular" and "radical" seem equally inapt categorizations) that I reproduce them here. The poet, walking through a graveyard populated with the remains of village peasants, admonishes the reader not to mock or disdain "the short and simple annals of the poor":

Perhaps in this neglected spot is laid

Some lieart once pregnant with celestial fire,

Hands, that the rod of einpire might liave sway'd,

Or wak'd to extasy the living lyre.

But Knowledge to their eyes her ainple page

Rich with the spoils of time did ne'er unroll;

Chill Penury repress'd their noble rage,

And froze the genial current of the soul.

Full inany a gem of purest ray serene,

The dark unfathom'd caves of ocean bear:

Fnll inany a flower is born to blush unseen,

And waste its sweetness on the desert air.

Some village-Hampden, that with dauntless breast

The little Tyrant of his fields withstood;

Soine mute inglorious Milton liere inay rest,

Some Cromwell guiltless of his country's blood.

T. GRAY, Elegy Written in a Country Church Yard, lines 45-60, in The COMPLETE Poems of Thomas GraY 39 (Start \& Hendrickson eds. 1966). 
how they treated Him when He was hungry and thirsty, a stranger, naked, sick and in prison: To those who answer, "Lord, When did we see you [so]"?, He will respond, "As you did it to the least of these iny brethren, you did it to ine."38 An arresting (and soinewhat less supernatural) example is a statement that Kazantzakis attributes to Francis of Assisi. His companion, Brother Leo, discovers Francis freezing with the cold in his hut on a mountainside, and implores him, "let me gather some wood and hight a fire for you." Francis answers: "Go, Brother Leo, go throughout the world, and if you find a fire in every hut, every poor cottage, then come back and hight one in my hearth. If even a single man in the world is shivering, I must shiver with him." 39

The Marxist idea of class-consciousness is, I believe, at bottom, a secular route to a similar goal, to transforin the consciousness of "individuals" from one oriented toward coinpetitive success to one that views the concept of individual success as self-contradictory. Addressed as it is to the consciousness of people lacking wealth and status, it seeks to achieve this end through tapping feelings of anger, oppression, and liope. Francesco Bernardone was the son of a wealthy merchant of Assisi, and an awakening of his "class consciousness" would hardly have led him to his destiny.

The refusal to regard even one's rudimentary privileges as any more deserved than they would be in the hands of one lacking them is often viewed by those not sliaring its foundation as a demgration of one's own desert, a form of self-abnegation or "guilt-tripping." From within a radical perspective, however, it is rather a reflection of the idea that the desert of the disfavored is far greater than is usually acknowledged.

Froin these premises, a radical perspective sees the entire scenario of the problem as a series of abuses. What a conservative perspective values as privately ordered allocations of responsibility, a radical perspective sees as the systematic demal of responsibility, as each actor seeks to transfer it elsewhere: Smith and Sinall vis-a-vis Stone, ESM vis-a-vis Clark, ESM and Clark vis-a-vis White. ${ }^{40}$ Each of the five is in significant

38. Matthew 25:40.

39. N. Kazantzakis, St. Francis 337 (1962). Consider this contemporary Catholic expression: "Mary was a displaced person and a refugee; the daughter of an oppressed people; the mother of a prisoner put to death on a cross." NATIONAI CONFERENCE OF CATHOLIC Bishops, ONE iN Christ Jesus: A Pastoral Response to the CONCERNS OF WOMEN For ChURCH and SOCiETY, para. 137 (2d Draft, April 3, 1990).

40. One should not lose sight (as the law encourages one to do) of Ms. Parker, employed by ESM to telephone debtors, and of the Pizza King manager, employed to operate a fast-food facility at maximum profit. It is only the confiuence of their, and ESM's, actions that produces the effect on Randy White's life. ESM is frec to structure tlie relations among these actors so as to maximize their effeetiveness in debt collection, but to mimimize its accountability to White; and neither Parker nor the manager is thought to liave "done anytlimg" at all. 
degree seeking to get more than he or she gives to the "transactions" with the others. Smith and Small come to the enterprise with valued impulses-to make something socially useful, to teach others-and are unable to implement those impulses without commoditizing them, without "selling" a "product." White acts in large part out of the valued human impulse to raise his child to be a fully enfranchised citizen, and he cannot begin to do that without turning himself imto a "consumer," and his son into a "good student," that is, a more marketable commodity. Within the ESM operation, Stone and Clark, whose work-keeping books, taking orders, and making deliveries-is a form of semi-skilled labor compared to the creative inputs of Small and Smith, are the primary shapers of the face that ESM presents to the world.

A radical perspective is at best ambivalent about tle social value of consumer protection laws or other forms of regulation that are so important from a hiberal perspective. It tends to beheve that at bottom sucli regulatory measures may do more harm than good. Their success in limiting what the liberal perspective regards as abuses is inevitably constrained by the strength of the conservative perspective, which views them warily. More fundamentally, regulatory responses do not even purport to address the systemic abuses that concern the radical perspective. Their function therefore is to legitimate what remains illegitimate. Indeed, a radical perspective views the function of the law much as a conservative perspeetive does, that is, as facilitating private activity, althougli it is of course condemnatory, ratlier than celebratory, of that function. 41

More broadly, a radical perspective does not accept the consciousness that is at the heart of mucli consumer-protection thinking. The notion that one can buy happiness by buying wisely and effectively-the Consumer Reports mentality-is, from a radical perspective, a deepseated social evil. Randy White is, to be sure, taken advantage of by ESM and Clark, who regard him only as a means to their end (profit). His oppression would not cease, however, if he could have bouglit the software for less money, if the computer had worked well, or even if its use had succeeded im improving his child's grades. For it is rooted in his thinking of himself-that is, being socialized throughout his life to think of himself-as a failure, as deserving to live poorly, because of his educa-

41. In a conservative perspective, this facilitation takes the form of legal principles that support private ordering and proclaim the legitimacy of existing allocations of power as consistent with the rule of law; see supra text accompanying note 18. In a hiberal perspective, it takes the forun of legal principles that "balance" private and public decisionmaking, and legitimize the consequent reallocation of power as overcoming the abuses of an unregulated market; see supra text at p. 427 . From a radical perspective, this differeuce is of little significance. 
tional and occupational attainments; and of thinking - that is, being socialized throughout his life to think-of success and failure as a matter of his ability to trade with his fellows so as to increase his material possessions and acquire the intangible recognition that goes with them.

A radical perspective struggles to know where to turn, given these premises and perceptions. That uncertainty, coupled with the fact that the law has almost never even momentarily responded affirmatively to it, makes it difficult to describe further a single perspective. One approach, as applied to the context of the problem, would adopt as a pohtical goal reversal of the dominance of produccr/creditor over debtor/buyer interests. There is a tension over even the espousal of such a goal, because it contradicts the premise-central to a radical perspective-that power is self-reinforcmg. From that premise, any incremental shift in power froin producers to consumers is by definition illusory, and essentially a legitimating mechanism. Only the total shift that would accompany genume revolution can avoid contributimg to producer hegemony.

Another approach that can be taken from within a radical perspective is to look toward a withdrawal from market consciousness, from the commodification of all aspects of human interaction. Necessarily, it appears-whether in concept or only in actual fact is not clear to me-such withdrawals seem possible only as individual acts of personal transformation. Nevertheless, even one holding a radical perspective sometimes finds it difficult to resist the tendency to see such individual acts of transformation as laying a foundation for societal transformation.

As for the role of the lawyer from a radical perspective, to represent White ${ }^{42}$ means something different than simply enabling him to save $\$ 1,000$, get the television or win some other "thing," or win disputes over unconscionability law or the enforcement of contracts. One approach emphasizes enhancing the effectiveness and protecting the autonomy of pohtical activists and organizations, ${ }^{43}$ the area of "consumer protection" has been an unusually infertile field by that criterion. Another is to

42. The discussion that follows focuses on the lawyer's rolc as counsel for White, in a litigation or pre-litigation setting. One narrowing consequence of that context is that the question of the application of a radical perspective to the circumstances of some of the other actors in the story, see supra note 8, tends to be suppressed. To struggle to offset that consequence would make the task of fully carrying out a radical perspective even more daunting, in part by inultiplying the attendant theoretical and practical problems, but also by calling upon the radical lawyer to leaven his or her identification with Randy White with a ineaningful identification with the circumstances of other actors, who in the immediate context may be seen as contributing to White's oppression. These lurking difficulties inay account in significant part for the wholeheartedness witl which lawyers working from a radical perspective often embrace the instrumental adversariness of the litigation process.

43. One serious effort to address the rationale and difficulties of such an approach to the practice of law is Wexler, Practicing Law for Poor People, 79 YALE L.J. 1049 (1970). 
struggle to overcome the dichotomy, which my analysis has posited, between the liberal and radical perspectives, seeking to infuse the day-today choices of "liberal" practice with the insiglits suggested by a radical perspeetive. Sucli an effort tries to steer clear of two polar liazards: to avoid adopting-falling prey to, some would say-the "nothing can cliange until everything clianges" consciousness of a pure radical view, and to avoid succumbing (more tlian momentarily, at least) to the strong pull that tlie practice of law has toward regarding "radical" insights as just too counter-productive to liold on to. 44

A "radical" approach tliat remains insistent on focusing on Randy White himself views tle idea of representation as calling upon his lawyer to take tlie opportunity that thc threatened suit presents to einpower White, to enable him to transform his consciousness. To do this, White needs first to see himself as a victim of abuse, rather than as someone who (once again) has made a mess of things and deserves to be onedown, to see himself as a plaintiff rather than a defendant. The law of unconscionability plays its most useful function here, serving to transform a debtor like White from a welsher-unable to pay his debts because of his improvidence-into one who lias been unfairly taken advantage of, one who does not in fact owe anything, but is rather a potential counter-claimant. It is essential to White's liberation tliat he come to recognize that lie does not deserve his fate, and a radical perspective in this regard accords the coneept of unconscionability genume validity, ratlier than simply a legitimating function.

However, White must pass through victimhood, for his disempowerment goes far beyond Stephen Clark and the computer. His very conception of what it ineans to be a success or a failure, whether with respect to his children or his work, stands in the way of his ever truly becoming free. As long as lie continues to view success, dignity, and the like im terms of money and status, his only rcal hope of achieving them is to win the lottery. True representation wonld help him to address the real source of his mnltiple vulnerabilities.

To perceive this agenda of representation is immediately to recognize the monumental difficulties inherent in actualizing it. A radical perspective finds it extremely difficult to articulate the professional stance

44. Two preeminent theoretician-practitioners of the legal services "movement" of the 1960 s and 1970s, Gary Bellow and Edward Sparer, contributed greatly to this struggle through their law practices, in legal-service lawyers training programs, in their law school teaching, and in their writing. For examples of the latter, see Bellow, Tuming Solutions into Problems: The Legal Aid Experience, 34 NLADA BRIEFCASE 106 (1977); Sparer, Gordian Knots: The Situation of Health Care Advocacy for the Poor Today, 15 Clearinghouse REv. 1 (1981); Sparer, Fundamental Human Rights, Legal Entitlements, and the Social Struggle: A Friendly Critique of the Critical Legal Studies Movement, 36 STAN. L. REV. 509, 552-67 (1984). 
that would inplement its insights, not only in the concrete realities of day-to-day practice on behalf of consumers like White, but even in theory. Indeed, to address the question in the context of an attorney's relation to White as an individual client is only to scratcli tlie surface. The difficulties of that question pale in comparison to two others, which tend to come to awareness as soon as one endeavors to think of White, the "individual" "client," in a non-reifying inanner-that is, one that does not distill out his "interest" regarding the ESM purchase from his overall personhood:

First, what degree, inanner, and purpose of interaction shonld White's lawyer seek to have with his family (for it is plain that White's consciousness is not severable from that of his family)? One reason why this question is often not squarely faced is that it suggests ways in which a truly radical representation of White appears to take on soine of the qualities of social work or therapy, which a radical perspective tends to scorn as inconsistent witl a stance of militant pohitical conbativeness. ${ }^{45}$

Second, low sliould and can a lawyer seek to communalize the representation of a client like White beyond his family setting? The question arises not in the hiberal, "law reform" sense of generatimg additional plaintiffs in order to achieve a greater effect on ESM and other producers through the assertion of a larger voluine of legal clanns, but in the more fundainental sense of enabling White to see that the problem presented to him by ESM is one that he has in common with others, and that one route to his einpowerment is for him to seek solutions as part of a coinmumity. The feminist inovenent lias done inuch to address questions such as this one in contexts in which gender is an aspect of disempowerment. The saine may be said of soine approaches to legal representation of members of racial and ethnic minorities. It is far more difficult, however, even to conceive of the application of an analogous approach to oppression arising froin a inarket economy itself. ${ }^{46}$

Notwithstanding the formidable quality of these barriers, a small but significant body of literature seeks to coine to grips with thein. Peter Gabel and David Harris, for example, assert that "the very public and political clraracter of the legal arena gives lawyers, acting together with

45. The work of the Institute of Labor and Mental Health, Oakland, Calif, is a rare example of an effort to integrate the "therapeutic" and "political" approaclies.

46. Bear in mind, again, that in this context the effort is to find ways not to bring pressure to bear on creditors or law-makers, but rather to transform the consumer consciousness of the Randy Whites of the world, in his child's school no less than his living room. There was a time when the labor movement sought to play a role that addressed some aspects of this effort, but long before it was deprived of much of its economic and political power, it for the most part enbraced rather than sought to transcend consumer consciousness. See, e.g., D. MONTGOMERY, THE FALL OF THE HOUSE OF LABOR (1987). 
chents and fellow legal workers, an important opportunity to reshape the way that people understand the existing social order and their place within it." 47 This literature emphasizes the need to reconceptualize the process of collaboration with chients and lay people. Gerald López has described the task of a lawyer seeking to represent "the pohtically and socially subordinated" in these terms:

Anticipating and responding to the problems of the politically and socially subordinated demands . . knowing how to work with chents and not just on their behalf; it demands knowing how to collaborate with allies rather than ignoring their actual or potential role in the situation; it demands knowing how to take advantage of and how to teach self-help and lay lawyering and not just how to be a good formal representative; and it demands knowing how to be part of, as well as knowing how to build, coalitions, and not just for purposes of filing a lawsuit. 48

Lucie White has emphasized the value of utilizing "the margins of the lawsuit," as a ineans of creating "parallel spaces" for chents and others to "engage among themselves in reflective conversation ...."49

This scholarship seeks to integrate a clear-eyed recogrition of the magnitude of the challenge with an abiding fidehty to a radical vision of lawyering.

\section{REFLECTIONS}

Buddha's teaching is only a raft

to help you cross the river,

a finger pointing to the moon.

Don't mistake the finger for the moon. ${ }^{50}$

47. Gabel \& Harris, Building Power and Breaking Images: Critical Legal Theory and the Practice of Law, 11 N.Y.U. REv. L. \& Soc. Change 369, 370 (1982-1983). This path-breaking article is an attempt to support and give content to the claim quoted in the text.

48. López, Training Future Lawyers to Work with the Politically and Socially Subordinated: Anti-Generic Legal Education, 91 W. VA. L. REv. 305, 356 (1989). Anthony Alfieri has explored a related approach. See Alfieri, Reconstructive Poverty Law Practice: Learning Lessons of Client Narrative, 100 YALE L.J. 2107 (1991); Alfieri, The Antinomies of Poverty Law and a Theory of Dialogic Empowerment, 16 N.Y.U. REv. L. \& SoC. ChANGE 659 (1987-1988).

49. White, Mobilization on the Margins of the Lawsuit: Making Space for Clients to Speak, 16 N.Y.U. Rev. L. \& Soc. Change 533 (1987-1988). She writes:

In these "parallel spaces," clients could speak their own stories of suffering, accountability and change, free from the technical and strategic constraints imposed by the courtroom.... These rituals would not be instrumental in the narrow sense of causing a court to order change. But they would serve the broader goals of teaching others about themselves and their reality and giving the participants a momentary experience in the exercise of power.

Id. at 546. Anita Hodgkiss finds similar potential outside the litigation framework in an avowedly radieal approach to the right to petition the government. Hodgkiss, Petitioning and the Empowerment Theory of Practiee, 96 YALE L.J. 569 (1987).

50. Thich Nhat Hanh, Being Peace 89 (1987). 
I have lived my life,

Seeking all that's still unsung;

Bent my ear to hear the tune,

And closed my eyes to see. 51

The principal question that the foregoing discussion raises in my mind is whether and how it is helpful to think about questions of legal regulation, law practice, and mequality in the way that $I$ have attempted here, rather than to do so in the more traditional manner of appraising the relative merits of contending positions respecting particular legal norms or patterns of human interaction, and making an argument for one answer or another.

First, I think it is clear that the differing responses of judges to relatively narrow questions like those that would be posed by a lawsuit, ESM v. White, are better explained by the analysis I have suggested than by specifically legal principles of common-law precedent, statutory construction, or judicial procedure. This is not to say that legal principles are wholly indeterminate, nor that a judge's perception of the world through a particular perspective is wholly determinative of outcomes. It is to say that a significant channeling goes on, and that a judge's response to one legal issue may parallel his or her response to another, doctrinally unrelated one. ${ }^{52} \mathrm{I}$ beheve that a focus on perspectives does a more satisfactory job of explaining the judicial work product than does a more "legal" analysis. ${ }^{53}$ Needless to say, what is true for judges is true with respect to legislators, administrators, and voters. Thus, if we would understand the path of the law, we would do well, I suggest, to work at the task of more fully articulating differing perspectives on it.

51. The Grateful DeAd, ATtics of MY Life (Arista Records 1971).

52. Much of the volumes of controversy about "formalism," "nihilism," and "indeterminacy" that has been generated over this issue is in my view the product of excessive polarization. To me, the statement in the text is a moderate, ineasured, and not terribly momentous expression, supported by the experience of nearly all practitioners. For a useful discussion of both the "indeterminacy" and the "predictability" of legal doctrine, see Singer, The Player and the Cards: Nihilism and Legal Theory, 94 YALE L.J. 1, 10-25 (1984).

53. Consider, for example, the tension or contradiction between two relevant statements in the Official Comment to U.C.C. $\$ 2-302$, seeking to give content to the idea of unconscionability: "The basic test is whether . . . the clauses involved are so one-sided as to be unconscionable," but "the principle is ... not [one] of allocation of risks because of superior bargaining power." U.C.C. \& 2302, comment 1 (1978). For a discussion of this tension, see Leff, Unconscionability and the CodeThe Emperor's New Clause, 115 U. PA. L. REv. 485, 500 (1967). On the view espoused in the text, the direction in which one resolves this tension is responsive more to one's resonance with Romans 13:1 or, per contra, with Matthew 25:40 (see supra text aecompanying notes 13 \& 38) than it is to one's apprehension of the principles of statutory construction. Indeed, the principal burden of Leffs article, supra, is that much of the law interpreting U.C.C. $\$ 2-302$ is inconsistent with those principles. 
A second response has more to do with the effects of the approach I have taken on the patterns of one's own thinking. It proceeds from a consideration of a fundamental question about the basis on which each of us comes to look at law through one perspective rather than another. Is the decision simply a product of one's formative life experiences, including one's birth setting, or is it a inatter of choice, a matter upon which reflection, dialogue, or argument can be expected (if characterized by intellectual honesty and acumen) to work a change, to narrow differences, or to provide a basis for judging soine perspectives unacceptable in soine respects? Is it a inatter that it is appropriate to regard as public in nature, or is it more like the choice of one's spouse or one's rehgious practices or behefs-or the choice betwecn sushi and steak-appropriately the subject of private reflection, but not a matter regarding which we are to any degree accountable to one another?

In thinking about these questions, I find it helpful to begin (but only to begin) by acknowledging the difference between explanations and arguments or justifications, between causes and reasons. I believe that I respond as I do to the differing ethical and pohtical underpinnings of Justice Pitney's and John Woohnan's words largely because of formative, or transformative, moments in iny life, and not only because of their respective powers to compel belief. The fact that I am a Jew, an American, was born during the Great Depression, and came to political awareness during the Second World War, and had the childhood and the father I did, probably accounts inore for my responses than anything else that I might name. In my life, each of these eleinents contributed to a feeling of "Inarginality" and of identification witl the dispossessed, which in turn generated a perspective on law different from the dominant one. Martha Minow has described the process well:

The more powerful we are, the less we may be able to see that the world coincides with our view precisely because we shaped it in accordance with those views. ... [W] are [also] able to put and hear questions in ways that do not question ourselves. In contrast, the more marginal we feel ...., the inore likely we are to glimpse a contrast between soine people's perceptions of reality and our own. ${ }^{54}$

54. Minow, supra note *, at 73-74 (footnotes omitted). Carrie Menkel-Meadow has suggested, in writing about gender, that a number of qualities often associated with demographic characteristics may contribute to this result: Exclusion, oppression, and "the learned attention to caring and relationships" may help to create in women "an outsider's critical perception . . ., greater empathy ... and the ability to understand the world from the underside ...." Menkel-Meadow, Exploring $a$ Research Agenda of the Feminization of the Legal Profession: Theories of Gender and Social Change, 14 LAW \& Soc. INQUIRY 289, 312-13 (1989). Katherine Bartlett, making a similar point, asserts that "[t]he experience of being a victim . . . revcals truths about rcality that non-victims do not see." Bartlett, Feminist Legal Methods, 103 HARV. L. Rev. 829, 872 (1990). Nel Noddings, offering a different sort of feminist perspective, sees all people as potentially open to similar qualities by reason 
To say this is not to say that those aspects of my life determined my responses, for surely there are staunch admirers of Justice Pitney whose biographical sketch would appear much like mine; "cause" is not a mechanistic affair. ${ }^{55}$

Nor does the notion of "transformative" experiences connote only earth- or life-shattering experiences. My intensive work with legal services lawyers from 1965 through 1970, and iny experience with secular and religious forms of meditation during this past decade, are exaniples from iny own life. It is also innportant to recognize that transformation need not always inove one "left" on the spectrum of perspectives. Many people of iny generation, for example, moved toward a conservative perspective as a result of their experience with anti-semitism, financial success, or the social discord of the 1960 s.

This means, first, that for me to "argue" with Mr. Justice Pitney is im some sense a deceptive practice, the more so when we argue over specific doctrinal questions such as the scope of the pohice power or of judicial review, but to some extent even when we dispute over more fundamental questions such as that posed by the passage of his that $I$ have quoted. ${ }^{56}$ The logical and rhetorical constructs that each of us brings to bear, and puts at risk through dialogne, are in significant part proxies for more basic and inore cherished behefs that we do not expose to the same processes of dialogne. ${ }^{57}$

of their experience of caring and being cared for. N. NODDINGS, CARING: A FEMININE APPROACH TO ETHICS \& MORAL EDUCATION 5, 79-80 (1984).

What these writers have observed with respect to gender may also be said of race. See, e.g., Delgado, supra note 3, at 2412-14.

55. Robert Burt has written an insightful and elegant portrayal of the role of Justices Brandeis' and Frankfurter's "outsider" positions in the developinent of their very different world-views. See $R$. Burt, Two Jewish JUSTICES: OUTCASTS IN THE PROMISEd LAND (1988).

56. See supra text accoinpanying note 15.

57. Coinpare Gerald Frug's depiction of "argument as character":

When we respond, "yes, that's what I think" after listening to another's arguments, we expose and foster an aspect of our own character, advancing a conception of who we consider ourselves to be. Arguments ... move people toward a conception of themselves.

$\ldots$...

My claim is that you will be persuaded by what I have had to say to the extent that [the] kinds of ... appeals [I have inade] find a place in your own character, to the extent that they appeal to an aspect of yourself and to a way in which you experience the world that you recognize and want to nurture.

Frug, supra note 4, at 873, 926 (1988).

Michael Fitts has noted the attraction to "philosophical and legal writers" of "intellectual exchange" as an aid to "agreement on factual and ethical differences." Across a wide array of scholars and issues, he observes that "rational dialogne has been offered as a legitinate basis for helping to resolve disputes and inake public decisions." Fitts, The Vices of Virtue: $A$ Political Party Perspective on Civic Virtue Reforms of the Legislative Process, 136 U. PA. L. Rev. 1567, 1584-85 (1988). My belief is that it is an occupational hazard of the "life of the mind" to exaggerate the extent to which rational discourse can play such a role. Reinhold Niebuhr's observation remains apt: "Modern 
It is not a solution, moreover, for us simply to move from argument over legal doctrine to argument over underlying perspectives or worldviews. Putting aside the question whether it is possible to evaluate one another's world-views according to some demonstrable standard of truth, whether one of us can by argument or demonstration force any other (assuming we are both sufficiently honest and intelligent) to concede the point, most of us are not readily able to surrender our most deeply held behefs if called upon to do so by reason (as embodied in the result of the dialogue). ${ }^{58}$ Moreover, argument is a limited avenue of authentic evolution in one's world-view. It is often more calculated to defeat rather than to change another's perspective; it is addressed more to the position taken by another person than it is to that other person. ${ }^{59}$ Neither losing nor winning an argument is likely to be a transfornative experience. ${ }^{60}$

educators are, like rationalists of all the ages, too enamored of the function of reason in life." $R$. NiEbUhR, MORAL MAN AND IMMORAL SOCIETY XV-xvi (1932).

For a poignant example, see Tribe, Constitutional Calculus: Equal Justice or Economic Efficiency?, 98 HARV. L. REV. 592, 595 n.20 (1985). Professor Tribe describes three "early articles" of his, asserted to be "directly applicable to [his] current critique," and then observes: "Indeed, having written these articles over a decade ago, and being by no ineans alone in iny criticism of the limitations of utilitarian policy analysis, I am somewhat surprised by the teflon-like immunity of those who purvey this mode of thought." Id.

58. A classic illustration of the phenomenon occurs in the GoRGIAS, supra note 35. In what is perliaps the most genunie moment in the dialogue, Callicles responds to a long argument of Socrates: "Somehow or other I can't help being impressed by what you say, Socrates; yet . . . , I am not completely convineed." Id. at 126 . Socrates confidently responds, "perhaps if we go over the same ground more thoroughly you will be convineed," yet he succeeds only in reducing Callicles to silence, and is finally forced to observe: "Discussion between you and ine is an absurd affair; all the time we have been talking we have never ceased to revolve in an endless circle of mutual misunderstanding." Id.

59. For a provocative description of the "rhetoric of advocacy," see Wetlaufer, Rhetoric and its Denial in Legal Discourse, 76 VA. L. REv. 1545, 1557-60 (1990).

A thouglit-provoking point of departure, which I would not dismiss despite its secming overstatement, is Sally Miller Gearhart's perception that "any intent to persuade is an act of violence." Gearhart, The Womanization of Rhetoric, 2 WoMEN's STUD. INT'L Q. 195 (1979). "[E]xplor[mg] the distinction between change and intent-to-change," she espouses a shift away froin a "conquest" or "conversion" model of dialogue. Id. at 197.

In a richly rewarding essay, Emily Fowler Hartigan seeks to redecm, rather than discard, persuasion. Writing of "law as invitation," she describes it as "a gentle draw, nore than a compelling force." Hartigan, The Power of Language Beyond Words: Law as Invitation, 26 Harv. C.R.-C.L. Rev. 67, 89 (1991).

These authors, using modes of expression that may be termed "feminist" or "literary," are seeking to bring to our awareness an alternative to what James Boyd White has described as a generally unrecognized paradigm of "discourse [as] structurally coercive, in the sense that the writer seeks to prove something even to an imwilling reader who resists with all his might until forced by factual or logical demonstration to yield." White, What Can a Lawyer from Literature?, 102 HARv. L. REv. 2014, 2017 (1991). See also infra text accompanying notes 88-91.

60. It is imiportant to distinguish two-party "arguments" or conversations, which the statements in the text have in mind, froin the three-party arguments that go on in a courtroom. A lawyer engaged in "oral argument" is not seeking to persuade an adversary, but to defeat lim or her by persuading the adjudicator. Typically, that is done within the coustramts of legal doctrine while 
Recognition of the salience of underlying perspectives in channeling legal analysis, and of the contingent quality of underlying perspectives, can help-in ways that reasoning or argument cannot-to bring about an important shift. First, those who find the conservative perspective significantly probleinatic inust struggle to retain their faith in the wisdoin of their own perspective when faced with the inany contexts in which the law has been significantly unresponsive to it. If I nay borrow iny own words:

[T] here is a ring of inevitable "rightness" in many aspects of the traditional value structure. They secin to describe the world as it really is. Intermittent stirrings to act in violation of the traditional teaching seem hopelessly visionary and out of touch with reality. The result is a profound sense of alienation and resignation, 'when the choice between despair and illusion seems unavoidable. ${ }^{61}$

The "juggeruaut" quality of inuch legal reasoning exercises a profoundly repressive effect on inany lay persons, law students, and lawyers. There is a dual inessage that, first, the inatter is not the contestable one of "perspective" at all, but is determined by soine legal principle that one cannot reputably dispute, and, second, that the doctrine makes deeper sense because there is an underlying perspective that makes it coherent

attempting more or less subliminally to tap those underlying perspectives that will favor the advocate's position. Although a good lawyer can at times succeed in presenting a case in such a way that it engages, or steers clear of, relevant perspectives of the decisionmaker, he or she tends to take the latter's underlying world-view as a given. Rare is the counsel who has or can take the opportunity to transform the imderlying perspective of the adjudicator. The classic exception is Stephen Vincent Benét's Daniel Webster, forensically wrestling with Satan on behalf of Jabez Stone. See S. BENét, The Devil and DANIEL Webster (1937).

I hope that the qualifications of language I have employed in the text will be borne in mind and credited. I am speaking of tendencies, likelihoods, and the like. I do not dismiss the possibility that rational dialogue can make clear the untenability of certain views, can change another's opinion, or can even transform a person's world-view. Nor do I beheve that we should spurn or scorn efforts to make these effects occur more often. I do assert that they do not happen easily; that rationality is often the servant as well as the master of emotion; and that there is a tendency, especially aniong intellectuals, toward wish-fulfillment in description.

For a useful discussion of some aspects of these questions, see Callahan, The Role of Emotion in Ethical Decisionmaking, 18 HASTINGs CTR. REP. 9 (1988). Callahan suggests that "just as reason tutors and monitors emotion, so too can our enotions tutor reason," $i d$. at 12 , and that it may be a mistake to regard the primacy of rationahity over emotion (values, underlying perspective) as per se desirable:

Rational tutoring of self or others assesses the inappropriate responses and substitutes others....

Rational persons may have a more difficult time noticing and assessing those less dramatic ... disorders consisting of deficits of emotion. ... [P]erhaps the greatest moral danger arises not from sentimentality, but from devaluing feeling and not attending to or nurturing moral emotions.

Id.

61. Lesnick, supra note 3, at $841-82$ (quoting R. UNGER, KNOWLEDGE AND Politics 24 (1975)). 
and just. ${ }^{62}$ Recognition of the salience and contingent quality of underlying perspectives can help those who do not share a conservative perspective from being overawed by the gulf between their own perspectives and those of authoritative expositors of the law, because it helps us to desacralize their authority, to realize that the authority of judges ${ }^{63}$ extends to the exposition of the law, but not to the enactment of the underlying world-view that informs that exposition.64

To conclude that all who expound "the law" do so from an underlying perspective need not rob their "law-doing" work of legitimacy, for it is central to iny thesis that the link between doctrine and underlying perspective cannot be wholly broken, and a judge's authority to adjudicate cases and controversies gives him or her authority to generate or apply doctrinal principles that gnide that process. It does, however, enable us to realize that the question of underlying perspective reinains "up for grabs." No official has authority to describe the world preclusive of a like authority in any other person, for the world-view of even the most powerful, intelligent, and respected person remains a view of reality, and not reahty itself.

A second consequence is that we can become less rigidly attached to our own perspective. Paradoxically enough, this result is supported by, and not in tension with, the first. The notion that "private" choices, like religious preferences, are inappropriate for conversation outside the fainily has its source, I beheve, in humanity's historic tendency to pumsh people, often lethally, for holding unpopular world-views. A truly credi-

62. This circular process can run in the opposite direction as well. "The law made sense of by our consciousness in turn makes our consciousness make sensc." Id. at 854.

63. I refer here to judges, but I believe that the point holds true as to executive and administrative officials, legislators, and voters-to enactment, interpretation, and application of the law-as well.

64. When the Conference on Critical Legal Studies was founded in 1977, the liberal and the conservative perspectives seemed each to take substantial turns in influencing the legal work product. To many in the Conference, the liberal perspective supported and justified outcomes that were more legitimating than emancipatory: what Duncan Kennedy, for example, described, and dismissed, as "the center liberal program of limited reform of the market economy and pro forma gestures toward racial and sexual equality." Kennedy, Legal Education as Training for Hierarchy, in The Polttics of LaW: A Progressive Critique 40, 48 (D. Kairys ed. 1982). Cf. supra text accompanying note 41 . The project of delegitimizing the liberal perspective was thought by many to have the predictable effect of moving many students and lawyers who stoutly rejected a conservative perspective toward a radical perspective. Today, the liberal perspective has been delegitimized as much from the right as from the left, and the conservative perspective, if not engaged with directly, now las a power it lacked a dozen years ago to compel grudging assent or, failing that, to reduce the unpersuaded to confused quiescence.

Joseph Singer has directly engaged the tendency within the liberal perspective to combime a recogrition of the contingent quality of values with a readiness to equate praginatic truth with the results of liberal processes of public decisionmaking. See Singer, Should Lawyers Care About Philosophy?, 1989 DUKE L.J. 1752, 1763-64. 
ble removal of the specter of coercion would go far, in time, to enable us to see that we can, and should, hold ourselves accountable in dialogue to our fellows for many of our supposedly most private choices. The coercion at work in the present context is more ideological than physical, but as powerful in its constraining force as in the liberating quality of its loosening. If my fundamental outlook on the world is seen as not subject to the governance of those who make, interpret, or apply the law, I need not cling to it unmodified or risk losing my identity altogether. If I understand that world-views different from mine are no more authoritative than mine, I can more safely acknowledge that they are no less so as well, and I can more freely listen to them for what I find of wisdom in them.

The result is that we can hold on more securely, yet less tightly, to our most basic behefs. Sir Isaiall Berlin has written eloquently of "the ideal of freedom to choose ends without claiming external validity for them,"65 and Richard Rorty describes as his "fundamental premise" the thought that "a belief can still regulate action, can still be thought worth dying for, among people who are quite aware that this behef is caused by nothing more than contingent historical circumstance."66 If I can beheve that I am right at the same time as I do not know that I am right, I do not compromise my commitment to the rightness of my behefs by being open to trying on the spectacles through which you-or Justice Pitneylook at the world, and attending to whatever lessons I learn thereby. ${ }^{67}$

Indeed, the very act of opening one's own perspective to the teachings of others provides the mcans to escape from the polar hazards of having to surrender it to the seeming authoritativeness of contrary perspectives or of seeking to safeguard it by clinging rigidly to one's favored form of ideological purity. ${ }^{68}$ The Taoist insight speaks profoundly to the question:

65. I. BERLIN, FOUR ESSAYS ON LIBERTY 172 (1969).

66. R. RORTY, CONTINGENCY, IRONY, AND SOLIDARITY 189 (1989). Compare Mark Edmundson's formulation, speaking of what (attributing the thought to William James) he terms, "simply, belief, a condition which eschews pretenses to theoretical mastery by being provisional, open to revision, but which is also, at least for the time being, committed." Edmundson, The Ethics of Deconsiruction, 27 Mrch. Q. REv. 622, 635 (1988).

67. Compare Arthur Lef's memorable essay, Unspeakable Ethics, Unnatural Law, 1979 DUKE L.J. 1229, refusing to be impaled on either horn of the dilemmatic choice between belief and knowledge.

The Vietnamese monk Thich Nhat Hanh has written of the Fourteen Precepts of the Tiep Hien Buddhist Order, the first three of which focus on the contingent and partial nature of our views and knowledge. "[T] embrace a view and consider it as absolute truth is equivalent to ending one's process of inquiry and enlightenment." ThICH NHAT HANH, INTERBEING: COMMENTARIES ON THE TIEP HIEN PRECEPTs 27-33 (1987). Buddhism, he writes, "speaks about its own teachings as a raft to cross the river and not as an absolute truth to be worshipped and safeguarded." Id. at 27.

68. Carl Rogers has written of the person whose values are "fixed and rigid, rather than fluid and changing": 
Be bent, and you will remain straight.

Be vacant, and you will remain full.

Be worn, and you will remain new. ${ }^{69}$

If the foregoing analysis is sound, it is also true, I beheve, that one's openness to the truths of others' perspectives is not contradicted by having evaluative responses, and preferring one's own evaluations to those of others. Katherine Bartlett has ably articulated a stance, which she terms "positionality," that transcends the supposed dichotomy between relativism and absolute truth:

The positional stance acknowledges the existence of empirical truths, values and knowledge, and also their contingency. ... [P]ositionality rejects the perfectibility, exteruality, or objectivity of truth. Instead, the positional knower conceives of truth as situated and partial. ... [T] he individnal perspectives that yield and judge truth are necessarily incomplete. No individual can understand except from some limited perspective. ... As a result, there will always be "knowers" who have aecess to knowledge that other individuals do not have, and no one's truth can be deeined total or final.

... Although I must consider other points of view . . ., I need not accept their truths as my own. Positionality is not a strategy of process and coinpromise that seeks to reconcile all coinpeting interests. . . .

Some "truths" ... seem to confirm the view that truth does exist ... if only I could find it. ... The problem is the human inclination to make this list of "truths" too long, to be too uncritical of its contents, and to defend it too harshly and dogmatically. ${ }^{70}$

Moreover, whatever the epistemological "bottoin line," there is much existential wisdoin in Gerry Frug's insight that "[a]nswers to [fundamental] questions may be tentative and contestable, but no one, in my view, actually experiences the task of answering thein as meaningless or arbitrary."71 It seems appropriate-indeed, perhaps necessary - to say a

The alternative [to holding them in rigid and unchanging fashion] would be a collapse of his values. Hence his values are "right"-like the law of the Medes and the Persians, which changeth not.

Because they are untestable, there is no ready way of solving contradictious. . . . If some of [his] conceptions were destroyed, what would take their place? This threatening possibility makes him hold his value conceptions more rigidly or more confusedly, or both.

C. Rogers, Toward a Modern Approach to Values: The Valuing Process in the Mature Person, in Person to Person: The Problem of Being human: A New Trend in Psychology 19 (1967).

69. Lao Tzu, Tao Te Ching, quoted in F. CAPra, The Tao of Physics 103 (1977).

70. Bartlett, supra note 54 , at 880-84. Cf. A. NeHAMAS, NiETzSCHE: LifE AS LiTERATURE 49 (1985):

Since every inquiry presupposes a particular point of view, it therefore excludes an indefinitely large number of others. [T]his does not imply that we can never reach correct results .... The fact that other points of view are possible does not by itself make them equally legitimate.... . Perspectivism ... is not equivalent to relativisin.

For a very similar approach, sec Cramton, Beyond the Ordinary Religion, 37 J. LEG. EDuc. 509, 513-16 (1987).

71. Frug, supra note 4 , at 876 . 
word about the ways in which I respond to each of the three perspectives that I have sought to articulate.

Repelled as I am by the central thrust of Justice Pitney's outlook, I nonetheless acknowledge much social value in the qualities of self-rehance and individual initiative that the conservative perspective seeks to protect. It is the unalloyed quality of its fidehty to those values, its bhthely self-justifying effort to impose those qualities on those who have to a significant degree been deprived of a genuine opportunity to choose or develop them, that renders the conservative perspective ultimately baneful. I cannot respect its attempts to transform a lack of empathy from a grievous defect of character into a ground of deeper social wisdom. ${ }^{72}$ Moreover, $I$ find in it too celebratory a mindset to provide a hospitable reception for the more somber perceptions of the others. ${ }^{73}$ These qualities seein too easily to lead to a certain blindness, a refusal to recognize that the conservative perspective too is a world-view, and not a set of Tablets. ${ }^{74}$ It has, at bottom, difficulty even understanding why one might want to "see efficiency as seeking to maximize more than the quantity of things that exists in the world, and freedoin as something inore than permission to coinpete with one another for scarce resources."75

It is in some ways the very "mushiness" of the liberal perspective that can give it the opeuness to constant revision that seeins to ine most essential. Its refusal to disregard the human suffering occasioned by the hegemony of the conservative perspective, its preference for pragmatism

72. David Richards has written insightfully about "the imagination required for the moral life": "Ethical reasoning depends on certain kinds of cognitive as well as emotional capacities, ... including the imagination required to think of oneself . . . as being the others affected by one's act." Richards, Moral Theory, the Developmental Psychology of Ethical Autonomy and Professionalism, 31 J. LEG. EDUC. 359, 363 (1981).

The relevance of this sort of "imagination" for the distributive issues that are the focus of this Article is powerfully suggested by this classic injunction:

When you gather the grapes of your vineyard, you shall not glean it afterward; it shall be for the stranger, the orphan, and the widow. You shall remember that you were a slave in the land of Egypt; therefore I coinmand you to do this.

Deuteronomy 24:21-22.

73. Robert Burt's study of Justice Frankfurter, supra note 55, is a compelling illustration of this mindset.

74. For a particularly fatuous example of this blindness, see the Statement of Principles of the Federalist Society. Invoking the ideas of the separation of powers and the duty of a court to say "wliat the law is, not what it sliould be," it describes as "prejudice" and "fiat" the "preferences" of those whose political views they deplore, and calls instead for continued fidelity to the "true purpose of the legal order." It lias no difficulty blandly informing us what those true purposes are. One example will suffice: support of "intermediate institutions sucll as families, churches, personal property, and states," institutions whose function is to help "to shield people from the government's full force." Federalist Society for Law \& Public Policy, Statement of Principles (copy on file with author).

75. Lesmick, supra note 3 , at 856 . 
over doctrine, are genuinely appealing qualities. ${ }^{76}$ To me, its most salient failings are a product of its strengths: Its tendency to generate an overly "rose-colored" perception of the extent to which regulation has actually succeeded in limiting abuses, and its failure to recognize or respond to the very practical costs of its refusal to engage with the theoretical premises of the conservative perspective, which opens it to the perception of being either sentimental or unprincipled. On a inore tangible level, the experience with Stalinism and the coercive force of repressive aspects of conservatisin reinforce these characteristics. The result is to leave the liberal perspective too vulnerable to falling into the conservative.

The radical perspective proceeds froin a vision of huinan life that I find powerfully attractive, and I believe that the vitriol that its utopianisin often engenders is a sign that many others find it so, albeit dangerously so, as well. It is a tragedy that those who dismiss it as "utopian" regard as "practical" the many horrific aspects of social life that pragmatic realisin seems to regard as the best we can hope for. ${ }^{77}$ Is there not in nearly all people at least a shred of resonance with statements like this one, attributed to Bertrand Russell? "Echoes of cries of pain reverberate in my heart. Children in famines, victims tortured by oppressors, helpless old people a hated burden for their sons, and a whole world of lonehness, poverty and pain make a mockery of what human life should be."78

Again, the failings of a radical perspective are embedded in its strengths. On a practical level, the very integrity of its critique disables it froin having enough to say about the here-and-now of particular issues, which invariably arise out of a context that from a radical perspective is pervasively flawed. More fundamentally, embodying or legitimizing as it does strong feelings of anger, even revenge, toward imjustices seen as grievous and pervasive, the radical perspective is beset by a tendency toward self-righteousness, and by a tendency to polarize rather than to synthesize anger and compassion. These tendencies mix poorly with temporal power, and the history of radical movements that succeed in taking control of a country ouly to lose their soul is a sobering one at best. ${ }^{79}$ It inay be that even in theory a radical perspective can play a

76. "[L]iberals are people who think that cruelty is the worst thing we do." R. RORTY, supra note 66 , at $\mathrm{xv}$.

77. From Right to Left, every one ... believes that his particular truth is the one to make men happy. And yet the coinbination of all these good intentions has produced the present infernal world ... [T] Utopia, a different one but perhaps a more costly one in the end.

A. CAMUS, NeITHER Victims NOR EXECUTIONERS 31 (1980).

78. Whitman, Governed by Three Passions, N.Y. Times, Feb. 3, 1970, at A1, col. 4 (commenting on the life and death of Bertrand Russell).

79. Camus' essay, supra note 77 , is a classic reproach addressed to the tendency of radicals to deny or apologize for the post-revolutionary betrayals of "successful" radical movements. 
useful role only as Prophet and never as Ruler, ${ }^{80}$ and one reason why I have emphasized religious, rather than Marxist or other secular manifestations of a radical perspective is that they more often are committed to combining an uncompromising sense of injustice with a refusal to let compassion be submerged by anger. ${ }^{81}$

It is, of course, far easier to look beyond one's feelings of anger from a position of relative privilege than from one that has suffered serious oppression. Yet, however understandable it may be for one in this latter position to scorn a call to view empathically the perspective of the oppressor, it remains true, I beheve, that a contmued refusal to surrender that scorn leads inescapably to a crippling distortion of a radical perspective. ${ }^{82}$

A central question, therefore, is how one who is reluctant to make that surrender comes to do so. I have attempted to address that question from inside-that is, not to justify a demand that another accede to my view or be found wantimg, but from a stance that acknowledges those aspects of myself that share the reluctance. The answer I find is that the growth in awareness of a strong and genume sense of gratitude unlocks the door to a redeening integration, and that even serious feelings of oppression are not contradicted by that sentiment. Again, it is in the rehigious tradition that this imsight is most commonly found. Yet, the benefit of the insight may be had by those who do not share that tradition, as well as by those who do. Consider this statement from the Christian theologian Jaines Gustafson, which I invite you to reflect upon, embedded in its theological settimg or separated from it as you prefer:

There is in [the experience of gratitude], a natter of trust and of hope which is only in part confirmed in human experience .... Honesty requires the admission that it is difficnlt to be grateful to God for life when it gives no concrete opportunities for human fulfillment, when those who have been sustaining and meaningful to us are brutally taken away, and when whole communities are suppressed and de-

80. It is, however, part of the truth that the post-revolutionary history of most leftist revolutions has in significant measure been shaped by the savage ferocity of the reprisals sought to be visited upon them. Self-righteousness is a quality not monopolized by radicals.

81. For examples by a Buddhist monk and a Catholic missionary priest, respectively, explicitly addressing the need for this commitment, see Thich Nhat Hanh's poem, Please Call Me By My True Names, in INTERbeing: Commentaries on the Tiep Hien PReCEPTS, supra note 67, at 62-64, and D. DORR, SPIRrTuALITY AND JUSTICE 1-2 (1984).

82. Recall, in this connection, Bertolt Brecht's lament:

Even the hatred of squalor

Makes the brow grow stern.

Even anger against imjustice

Makes the voice grow harsh. Alas, we

Who wished to lay the foundations of kindness

Could not ourselves be kind.

B. Brecht, To Posterity, in Selected Poems 173, 177 (1947). 
stroyed by the demonic and destructive activities of men, and indeed, of nature. Conscientious religious men have a quarrel with God not only after Auschwitz but after earthquakes, not only in the midst of an unjust war but after assassinations of leaders who have symbolized hope and justice and peace. Like Job and Jeremiah, we too have occasion to curse God for the day that we were born. To gloss over such human experiences would be to engage in cheap religious rlietoric.

Nonetheless, the occasions for gratitude, though they come in sinall sizes and with less frequency than we might desire, remain as some testimony to the goodness of life and even evoke our celebration. For all our anxieties and struggles, we are grateful to be, to exist. Most of us have been loved beyond our deserving, forgiven when we dared not beheve it possible, sustained by the patience of others when they have had grounds to reject us. We have received from the sustaining powers of the sun and the earth, the social order and the culture, more than we could ever claim to deserve. These experiences point to the goodness of God, and they confirm the goodness which we dimly apprehend. And we are grateful.

Gratitude, like dependence, can be oppressive and destructive if it carries also an obhigation to cower before those who have given life to us. But it can be liberating if the gifts we receive are given freely, graciously, and in love, rather than as bribes or for the self-glorification of the giver. This is the importance of the experience of God as beneficent and gracious: what is given is freely given in love. It is not inerely what we earn by our accomphshments, but it is already there for us to respond to, to appropriate, to participate in.

The experience of gratitude is a pivot on which our awareness of God's goodness turns toward our [moral] life. ... What is given is not ours to dispose of as if we created it, nor ours to use to serve only our own interests, to mutilate, wantonly destroy, and to deprive others of. Rather, if life is given in grace and freedoin and love, we are to care for it and share it graciously, freely, and in love. ${ }^{83}$

The Jewish tradition of reciting the Hebrew prayer, Sheheheyanu, at the time of every significant event during the year, is for me a profound recognition of the centrality of this sense of gratitude: Blessed is God, "who has given us life, and sustained us, and brought us to this season." It is more than simply an expression of gratitude, however. It can be a source of it as well -and a powerful transformative force in one's life.

To acknowledge a resonance of these sentiments with something within that seems authentic need take nothing away from an awareness, personal or einpathic, of the grievous and pervasive injustice of central aspects of the social order. It inakes it possible to recognize that the state of being oppressed and disempowered always exists in relation to others, and that few of us are oppressed so pervasively that there are not con-

83. J. Gustafson, Theology and Christian Ethics 169-70 (1974). 
texts in which we are privileged as well, even illegitimately so. ${ }^{84}$ It provides the means, I beheve, to hiberate the radical perspective from a suffocating and dangerous parochialism.

These evaluative thoughts, admittedly fragmentary though they are, suggest a recurrent theme that I find centrally helpful. The "truth" for which we must seek resides in the search for it, in an endless searchfrom within one perspective, to be sure-for the endlessly emergent, endlessly evanescent synthesis of the insights of each. ${ }^{85}$ Again, Katherine Bartlett's msight is pertiment and helpful:

[T] he key to increasing knowledge hes in the effort to extend one's limited perspective. Self-discipline is crucial. ... I cannot transcend iny perspective .... [b]ut I can improve iny perspective by stretching my imagination to identify and understand the perspectives of others. ${ }^{86}$

Each perspective has its own reasons to abjure the search: the conservative, susceptible to a failure to recognize that there is anything to search for; the liberal, prone to mistake its pragmatism for synthesis; the radical, scornful of the suggestion that its angry purity needs to be leavened. Each is grievously lessened, I suggest, by giving too much credence to those reasons. ${ }^{87}$

If the foregoing is sound, I do not contradict my acknowledgment that I do not know, but only beheve, that I am right and you are wrong, by inviting you (as long as I remain open to similar mvitations from you

84. Cf. Minow, supra note *, at 62-64.

85. In personal correspondence, Jack Balkin has felicitously described each ideology (to use his term) as "a placement and displacement, an emplasis and marginalization ... of various elements of social life ...." Letter from J. M. Balkin to author (Aug. 13, 1990).

86. Bartlett, supra note 54, at 81-82; see also Minow, supra note *, at 74: "We must stop seeking to get close to the 'truth' and instead seek to get close to other people's truths."; Winter, Bull Durham and the Uses of Theory, 42 StaN. L. Rev. 639, 685 (1990) ("Once we give up the notion of the transcendent position ... , '[i]mpartiality' ... is no longer a matter of an aperspectvial position, but rather an exercise of the empathetic ability to imagine what a question looks like from more than one side.").

A notable example of such an integrative vision, relentlessly faithful to the need to capture multiple perspectives simultaneously, while remaining cognizant of the impossibility of doing so fully, is Ansley, Stiming the Ashes: Race, Class and the Future of Civil Rights Scholarship, 74 ConNELL L.Q. 993 (1989).

87. Although I have sought to give nonrational modes of cognition greater recognition than they are usually given, and have to that extent deemphasized the value of rationality, I have focused entirely on cognitive processes as chosen avenues of productive change. I lave not written about noncoguitive processes such as transformative work or political experiences (although $\mathrm{I}$ have noted their salience in my own life, see supra text accompanying note 55). I do not mean by this choice of focus to assert the primacy of cognitive over noncognitive experiences, let alone to claim exclusivity of role for the former. Indeed, the two can operate synergistically in transforming consciousness. Not only is there enormous value in accounts of noncognitive experiences and in theoretical examinations of the processes by which they do their work, individual and collective efforts to discern and pursue such experiences have in themselves transformative potential. 
and others) to question your own spectacles, or try mine for a moment. An "invitation" is not an argument, ${ }^{88}$ although the tendency for it to lead to one is ever-present. 89 The difference between the two inheres principally in the fact that the former is addressed to the person of the hearer-it is what Warren Lehman has terined "speaking to the spirit," what Michael Perry has termed attemptimg to "open [another's] eyes to [another] way of 'seeing' "90_and it speaks from the person of the speaker, brimging reasons and argument into a dialogue in a manner that neither inasks underlying world-views nor seeks to impose them (whether by force of position or of rhetoric). ${ }^{91}$ It is neither writing a

88. Coinpare Ruth Colker's dichotomization of "dialogue" and "argument" in Colker, Feminist Litigation: An Oxymoron? -A Study of the Briefs Filed in William C. Webster v. Reproductive Health Servs., 13 HARV. WoMEN's L.J. 137, 142-44 (1990).

Emily Fowler Hartigan has explored the concept of "invitation" (as distinguished from "cominand") in a inanner that, to use her term, "beckons . . . deeply." Hartigan, supra note 59, at 89.

89. In personal correspondence, Lucic White has observed that "the wisdom embedded in each of your three world-views . . . is so very vulnerable to distortion for social and political ends," and has described the primary challenge as "to understand the processes of distortion and appropriation that turn spiritual wisdom into a tool of domination." Letter from $L$. White to author (Sept. 8, 1990). The concluding passages of this Article are not so unuch a response to that challenge as they are an expression of an approach that, in my judgment, has genuine potential to neutralize those processes in one's own thinking and discourse. Except as the example might prove contagious, I have no answer to the question how one may seek to affeet the processes of others, those with whoin one is in direct interaction or, a fortiori, those in a larger community.

90. Lehman opens his perceptive essay by observing that it was written before he became aware of a substantial recent literature on the subject. Lehman, The Pursuit of a Client's Interest, 77 MiCH. L. REV. 1078 (1979). He notes that some losses, but also some advantages, result from his "iunocence." One advantage is that "the tone would have changed from meditation to argument: We are dealing with the most difficult problems of the interior and virtuous life. Ethical dilemmas do not resolve under the assault of argument. We innst speak inore gently to the spirit. I have not found the way to score poimts gently." Id.

Michael Perry asserts that, to Vietnamesc Buddhists, the claim that napalming babies is "bad" is not a value judgment, to be argued over but never proven. Rather, it is "a statement about reality-about the way the urniverse is constructed-and proving it to other persons consists of trying to open their eyes to that way of secing." Perry, Noninterpretive Review in Human Rights Cases: $A$ Functional Justification, 56 N.Y.U. L. REv. 278, 300 n.81 (1981).

The concluding section of Martha Minow's Foreword, supra note *, at 70-95, is a remarkable attempt to speak (as academics characteristically do) to the question of how judges should decide cases, but to do so (as academics almost never do) by speaking to the judges, rather than making an argument before thein, and by speaking not about disputed points of doctrine, but about how the ways in which they see the world affect their view of doctrine. See id. at 72.

91. Compare notes 59-60 and accompanying text.

William McAnich has briefiy, but effectively, described this stance in the teacher-stndent context. McAnich, Comment, in E. DVorkin, J. HimMELSTEIN, \& H. LesNick, Becoming a LAWYer: A Humanistic Perspective on Legal Education aNd Professionalism 187-88 (1981).

James Boyd White's description of what he terms the teaching of literature eaptures, with his characteristic insight and elegance, the mode of discourse about legal matters that $I$ am attempting to express:

This teaching of course does not take the form of propositions: it lies in the transformation of our sense of ourselves, and of our own language, that results from our engagement with the text. And what it teaches is not compulsory: it does not try to impose itself on your 
poem, nor hammering a nail into a board. It is motivated, to be sure, by a desire to affect the world-view of another person, but not only by that; it is also an expression of a desire to present oneself authentically to the other, and to the world. In both aspects, it shares with argument an instrumental quality, but it is not dominated by that quality.

This articnlation of the difference is avowedly evocative and fraginentary, rather than precise and complete. Nevertheless, I can often readily notice the difference; I mvite you to do the same.

will as a reader but rather invites you to engage in a process that will lead to a shift of understanding and of feeling.

White, supra note 59, at 2014 n.69. 